\title{
Off-design thermodynamic performances of a combined solar tower and parabolic trough aided coal-fired power plant
}

\author{
Hongtao Liu ${ }^{\mathrm{a}, \mathrm{b}}$, Rongrong Zhai ${ }^{\mathrm{a}, *}$, Kumar Patchigolla ${ }^{\mathrm{b}, *}$, Peter Turner ${ }^{\mathrm{b}}$, Yongping \\ Yang $^{\mathrm{a}}$ \\ ${ }^{\text {a }}$ Key Laboratory of Condition Monitoring and Control for Power Plant Equipment, \\ Ministry of Education, North China Electric Power University, Beijing 102206, China \\ ${ }^{\mathrm{b}}$ School of Water, Energy and Environment, Cranfield University, Bedford,
} Bedfordshire MK43 0AL, UK

*Corresponding author: Rongrong Zhai, Kumar Patchigolla E-mail: zhairongrong01@163.com,k.patchigolla@cranfield.ac.uk

\begin{abstract}
The solar tower and parabolic trough aided coal-fired power generation has been demonstrated as a promising technology and has potential advantages in utilisation of solar energy in a cost-effective manner. Due to introduction of solar energy, from the solar tower or parabolic troughs, increases to a certain extent, the steam temperature would be difficult to maintain and leads to safety concerns. Therefore, the limitation of integrated solar energy, considering the overlapped influence of different solar energy input, needs to be well identified and managed. This work considered a $600 \mathrm{MW}_{\mathrm{e}}$ integrated system as an example. Solar energy from parabolic troughs is used in the preheater while energy from the solar tower is used to reheat steam. The novelty of this study is the interaction of different solar energy input in fossil plants and its benefits is revealed for the first time. The maximum absorbed solar energy, considering the mutual effects of introduced
\end{abstract}


solar energy flows, are explored. Then the system performance under three different loads (100\%, $75 \%, 50 \%$ ) and hourly operational performance in four typical days are analysed. The paper shows that the feed-water extraction results in the enhancement of maximum solar energy absorbed by reheat steam extraction, is improved by $24.2 \mathrm{MW}_{\text {th }}(28.5 \%), 11.5 \mathrm{MW}_{\text {th }}(20.0 \%)$, and $5.6 \mathrm{MW}_{\text {th }}$ $(14.3 \%)$ as feed-water extraction percentages increase at the three load conditions. As a result, the minimum standard coal consumption rates are improved by $13.2 \mathrm{~g} / \mathrm{kWh}(5.2 \%), 10.7(4.1 \%) \mathrm{g} / \mathrm{kWh}$ and $9.0 \mathrm{~g} / \mathrm{kWh}(3.1 \%)$ respectively. In four typical days, the highest coal consumption reduction is reached in the summer solstice, which is 266.6-tonne, 202.8-tonne and 131.4-tonne under three different loads, while the highest coal consumption is obtained in the winter solstice.

Keywords: Solar tower; Parabolic trough; Coal-fired power generation; Off-design performances;

\section{Introduction}

Coal plays an important vital role in many developing countries, including those with significant energy challenges [1,2]. For many countries such as China, coal-fired power plants will remain dominant for a long time to provide much needed electricity, while, at the same time such plants are under great pressure from the increasing concern of environmental problems and $\mathrm{CO}_{2}$ emissions [3]. For many conventional coal-fired power plants, the improvement possibility to further reduce coal consumption rate is very limited after a series of internal modifications [4]. Expanding the application of renewable energy to restructure the energy source is essentially required. Compared with other renewable energy, such as wind power and photovoltaic energy, 
concentrating solar power (CSP) has the basic advantage that it can provide stable electricity under fluctuating and intermittent solar irradiation [5]. On the other hand, technical and economic obstacles hinder its extensive application, including high investment and relatively lower power block efficiency compared to coal-fired power generation due to the smaller scale [6]. Combining solar thermal energy with coal-fired power plants has potential benefits to reduce coal consumption in coal-fired power plants, improve solar-to-electricity efficiency and reduce investment via sharing boiler, regenerative components and turbines.

The integration of solar thermal energy and coal-fired power plant was first investigated by Zoschak and $\mathrm{Wu}$ [7]. The comparison of seven different schemes to introduce solar thermal energy into an $800 \mathrm{MW}_{\mathrm{e}}$ coal-fired steam power plant demonstrated the benefits of the integrated system in improving solar-to-electricity efficiency and saving capital cost. Then this integrated system was conceptualized by $\mathrm{Hu}$ and Yang et al. [8] and solar aided power generation systems have got increased attention in recent years. The integration of a coal-fired power plant with solar energy from parabolic troughs (SPCG) was mainly investigated early on due to the comparatively mature nature of this technology. Then, considering the higher working fluid temperature that can be approached in the solar tower than that in parabolic troughs, solar tower aided coal-fired power generation (STCG) was explored to achieve higher solar-to-electricity efficiency.

For SPCG systems, scholars explored many different integration schemes to achieve better efficiency and operational performance. Yan et al. considered solar 
thermal energy to replace different steam extraction that varies from $85^{\circ} \mathrm{C}$ to $330{ }^{\circ} \mathrm{C}$ to preheat feed-water [9]. Qin et al. compared 12 scenarios in a $300 \mathrm{MW}_{\mathrm{e}} \mathrm{SPCG}$ considering the combination of configurations and its operational behaviours [10]. Rech et al. investigated 20 integration schemes considering different loads and placement points [11]. Wang et al. developed eight virtual heat exchangers and its integration scenarios into preheaters [12]. Based on these studies, the highest-pressure feed-water preheater is generally considered as the preferred integration position for parabolic troughs. Then the thermal performance of SPCG was extensively investigated based on thermodynamic simulations [13-15] in aspects of off-design performance [16$18]$ and annual performance $[19,20]$. To comprehensively evaluate the system, different evaluation methods were performed to identify the effects of introduced solar thermal in energy, exergy, environment and economy aspects [21-24]. In most of these studies, the boiler is regarded as a 'black box' and the specific heat exchange processes of heaters are not calculated. Therefore, the influence of the solar input on the boiler operation is neglected. Recently, some critical components were then focused on considering the actual operating conditions, including parabolic trough tubes [25], direct air-cool condensers [26] and the boiler [27]. The dynamic performances of the system under a varied solar irradiation condition are also emphasized [28, 29].

In STCG aspect, the integration of solar tower thermal energy with the boiler is paid increasing attention. Exergy analysis on the design point performance of STCG was conducted based on advanced exergy analysis [30] and Sankey diagram [31] to identify the feasibility and the optimum scheme of STCG. Then the detailed boiler 
performance of a $660 \mathrm{MW}_{\mathrm{e}} \mathrm{STCG}$ in two schemes, with feed-water extracted from economizer outlet or steam extracted from superheaters inlet and heated by solar energy were investigated. Considering the requirement of basically unchanged steam temperature, the maximum extraction percentage was indicated as $8 \%$ and $30 \%$ in the two schemes [32]. Then Zhang et al. [33] and Li et al. [34, 35] explored the annual performance of STCG with superheaters partly replaced by molten salt-steam heat exchangers, with effects of thermal energy storage (TES) capacity considered. More recently the scheme with solar tower to reheat exhaust steam from the intermediate turbine are also performed by Li et al. [36]

In these studies, solar energy from parabolic troughs or the solar tower is integrated with coal-fired power plants separately, leading to a limited potential solar contribution considering boiler safety issues. In our previous study [37], the solar tower and parabolic trough aided coal-fired power generation (STPG) was first proposed, in which solar tower and parabolic troughs were both configurated to collect solar energy. Results showed the feasibility of STPG with improved cost-effectiveness and 7.83\%$11.88 \%$ more available solar exergy provided in this novel system compared to alternative systems under the same solar field investment conditions. However, the operation of this STPG, with different solar energy input, is more complicated due to the overlapping influence mechanisms of the introduced solar energy. When the introduced solar energy, from the solar tower or parabolic troughs, increases to a certain extent, the steam temperature might be difficult to be maintained, leading to safety issues. Therefore, the limitation of integrated solar energy, considering the effects of 
both reheat steam extraction and feed-water extraction, needs to be identified. In this study, a $600 \mathrm{MW}_{\mathrm{e}}$ STPG is studied as an example, in which part of the feed-water is preheated by parabolic troughs and part of the extracted reheat steam is heated by the solar tower. The novelty of this study is the interaction of integrated solar tower and the parabolic troughs solar energy is revealed for the first time. Then the maximum solar power that can be absorbed in the STPG system is identified under 100\% load, $75 \%$ load $50 \%$ loads. Besides, the variation of operational performance in four typical days are investigated.

\section{System description}

The composition and working flow of the basic coal-fired power plant and the integrated STPG are introduced in this section. The operational strategy of STPG in the coupled mode is also introduced.

\subsection{Basic coal-fired power generation system}

A typical $600 \mathrm{MW}_{\mathrm{e}}$ supercritical coal-fired power plant with a condensing steam turbine is considered as the benchmarking plant in this study, as shown in Figure 1. The feed-water from the condenser is preheated by extracted steam in the regenerative system, which comprises three high-pressure preheaters (PH1, PH2, and PH3), four low-pressure preheaters (PH5, PH6, PH7, and PH8), and a deaerator. After that, the preheated feed-water enters the boiler. In the boiler, the feed-water goes into the economizer (ECO) at first, and then enters the water wall heat exchanger. In the water wall, the water absorbs the thermal energy from the furnace flame, partly becoming steam and then goes into the steam separator (SEP). The steam in turn goes through the 
platen superheater $(\mathrm{PSH})$, rear plate superheater $(\mathrm{RSH})$, final superheater and enters the high-pressure cylinder (HP) of the steam turbine. After producing power, the steam from HP goes into the reheaters, which includes a horizontal section (LRH-H), vertical section (LRH-V) of low-temperature reheater, and final reheater (FRH). Later, the reheated steam goes into the intermediate-pressure turbine (IP) and low-pressure turbine (LP).

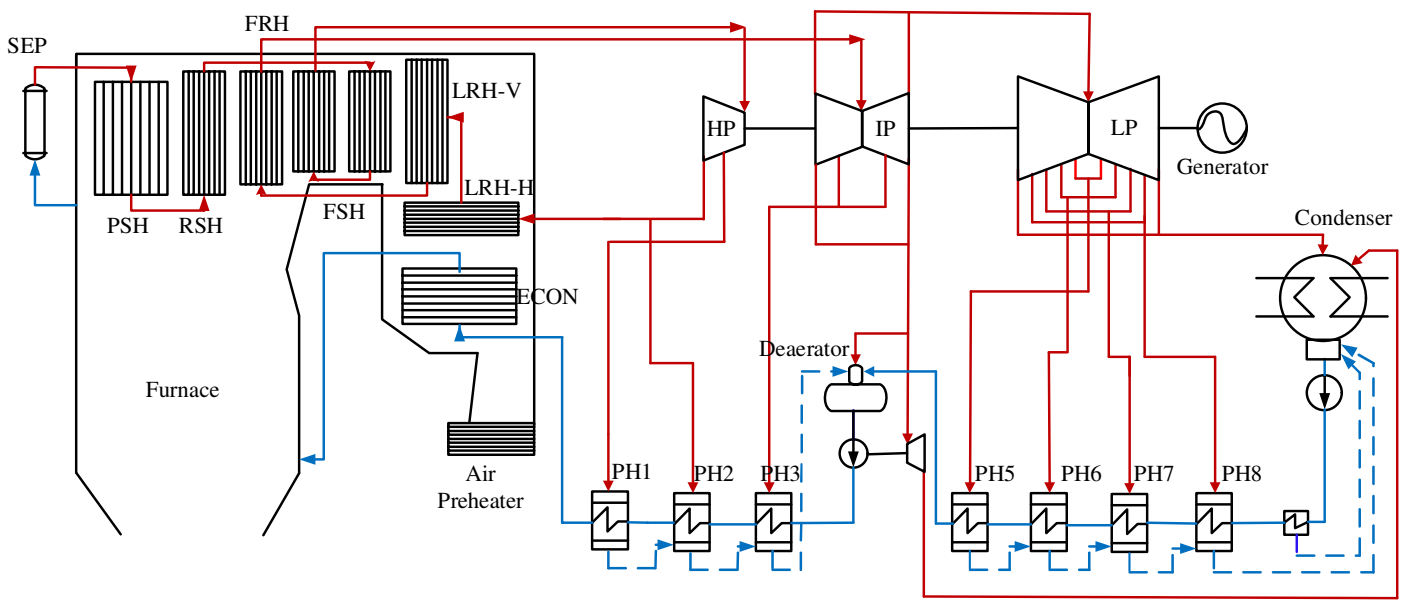

Figure 1. The diagram of $600 \mathrm{MW}_{\mathrm{e}}$ supercritical coal-fired power plant

\subsection{Solar tower and parabolic trough aided coal-fired power system}

This solar trough and tower aided coal-fired power system is composed of a solar tower system, parabolic trough system and conventional coal-fired power plant, as shown in Figure 2. The thermodynamic diagram of STPG system is shown in Figure 3. Heliostats reflect solar energy to the receiver to heat the molten salt (wt. 60\% $\mathrm{NaNO}_{3}+40 \% \mathrm{KNO}_{3}$ ) pumped from the cold tank through the receiver before going into the hot tank. When required, the hot molten salt is used to reheat cold reheat steam extraction in the high-temperature molten salt-steam heat exchanger (HMSE). In the parabolic trough collector field, solar energy is reflected to the vacuum encased heat 
absorber tube. The molten salt is pumped through the collector and absorbs solar energy at about $395{ }^{\circ} \mathrm{C}$. The medium-temperature molten salt is used to preheat feed-water extraction in the medium-temperature molten salt-water heat exchanger (MMSE).

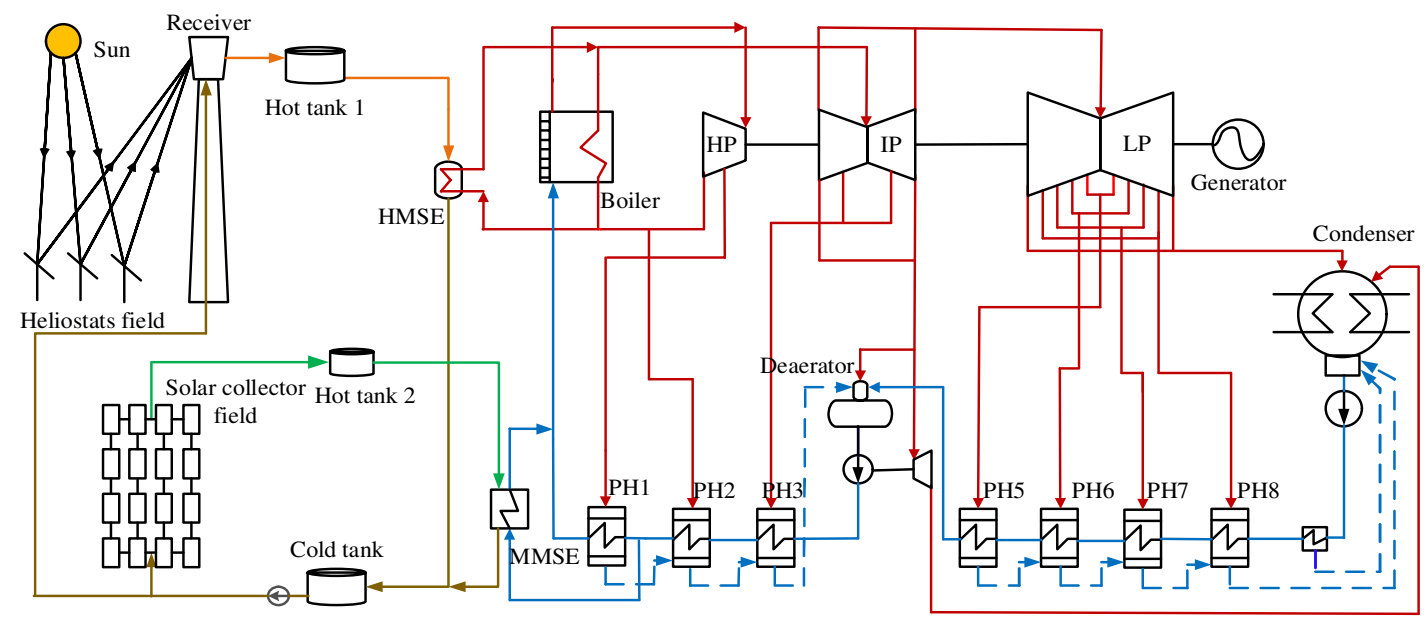

Figure 2. The diagram of the solar tower and parabolic trough aided coal-fired power system

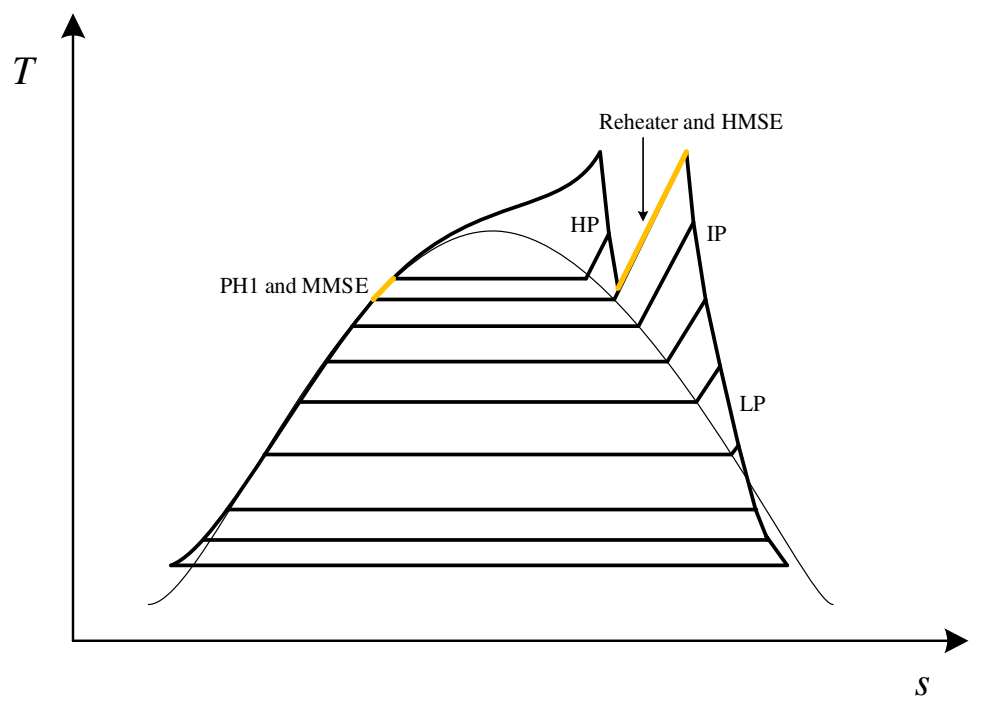

Figure 3. The thermodynamic diagram of STPG system

\section{Modelling and evaluation}

The mathematical model of solar tower components, parabolic troughs, TES and thermodynamic indexes are introduced in this section. The solar noon on the 21st March in Delingha $\left(97.37^{\circ} \mathrm{E}, 37.37^{\circ} \mathrm{N}\right)$ is considered as the design point of heliostat field and 
parabolic troughs.

\subsection{Heliostats and receiver}

The solar energy reflected from the heliostat field to the receiver is calculated as:

$$
\begin{gathered}
Q_{\text {receiver }}=A_{f} \cdot D N I \cdot \frac{\sum_{1}^{n} \eta_{\text {hel }_{i}}}{n} \\
\eta_{\text {hel }_{i}}=\rho_{i} \cdot \cos \theta_{i} \cdot f_{s b_{i}} \cdot f_{a t_{i}} \cdot f_{\text {int }_{i}}
\end{gathered}
$$

where $A_{f}$ is the effective area of heliostats, $\mathrm{m}^{2}$; and DNI is direct normal irradiance, $\mathrm{W} / \mathrm{m}^{2} ; n$ is the number of heliostats and $\eta_{h e l_{i}}$ is the efficiency of an individual heliostat, in which the effective reflectivity of heliostat with soiling $\left(\rho_{i}\right)$, cosine factor $\left(\cos \theta_{i}\right)$, shading and blocking factor $\left(f_{s b_{i}}\right)$, atmospheric attenuation factor $\left(f_{a t_{i}}\right)$, and interception factor $\left(f_{\text {int }}\right)$ are considered. The detailed calculation method of heliostat efficiency is established in MATLAB and validated in previous studies [38, 39].

The effective energy absorbed by molten salt in the receiver is calculated according to received solar energy and heat loss in the receiver:

$$
Q_{\text {rec }}=Q_{\text {receiver }}-Q_{\text {loss }, \text { opt }}-Q_{\text {loss }, \text { rad }}-Q_{\text {loss }, \text { cov }}
$$

where $Q_{\text {loss,opt }}$ is the heat loss due to optical efficiency, $Q_{\text {loss,cov }}$ is convective heat loss of the receiver, and $Q_{\text {loss,rad }}$ is the radiation heat loss of receiver. These heat losses in the receiver can be calculated as follows:

$$
\begin{aligned}
& Q_{\text {loss }, \text { opt }}=Q_{\text {receiver }}\left(1-\eta_{\text {opt }}\right) \\
& Q_{\text {loss }, \text { rad }}=\varepsilon \sigma\left(T_{\text {rec }}^{4}-T_{a m b}^{4}\right) A_{r e c} \\
& Q_{\text {loss }, \mathrm{cov}}=\alpha\left(T_{\text {rec }}-T_{a m b}\right) A_{\text {rec }}
\end{aligned}
$$

where $\eta_{\text {opt }}$ is the optical efficiency of the receiver surface; $\varepsilon$ is the emissivity of the receiver surface; $\sigma$ is the Stefan-Boltzmann constant, $5.67 \times 10^{-8} \mathrm{~W} /\left(\mathrm{m}^{2} \mathrm{~K}^{4}\right) ; T_{\text {rec }}$ is 
the surface temperature of the tube bundle, $\mathrm{K} ; T_{a m b}$ is the ambient air temperature, $\mathrm{K}$; $A_{\text {rec }}$ is the aperture area of the receiver, $\mathrm{m}^{2}$; and $\alpha$ is the convective heat transfer coefficient between the receiver surface and the surrounding air, $\mathrm{W} /\left(\mathrm{m}^{2} \mathrm{~K}\right)$;

\subsection{Parabolic trough collectors}

The solar energy collected by the parabolic troughs is calculated as follows:

$$
Q_{\text {col }}=D N I \cdot A_{\text {net }} \cdot \eta_{\text {col,opt }} \cdot K \cdot e_{\text {shad }} \cdot e_{\text {end }} \cdot e_{\text {clean }} \cdot e_{\text {avail }}
$$

where $A_{\text {net }}$ is the net aperture area of parabolic troughs, $\mathrm{m}^{2} ; \eta_{\text {col,opt }}$ is the peak optical efficiency of the parabolic troughs, $K$ is the incident angle correction considering cosine losses, $e_{\text {shad }}$ is the factor to include shading losses, $e_{\text {end }}$ is the factor to correct end-loss effects determined from the model, $e_{\text {clean }}$ is the factor to correct for actual mirror cleanliness, and $e_{\text {avail }}$ is field availability.

Heat loss in the collector field and pipes is also considered to calculate the thermal energy absorbed by working fluid due to the temperature difference between the working fluid and the ambient air:

$$
Q_{c o l, e f f}=Q_{c o l}-Q_{c o l, l o s s}-Q_{\text {pipe,loss }}
$$

where $Q_{c o l, l o s s}$ and $Q_{\text {pipe,loss }}$ are heat losses that occur in the collectors and pipes, respectively that are themselves a function of the working fluid temperature.

\subsection{Thermal energy storage}

The mass balance of the TES during the interval time is calculated as

$$
m_{i+1}=m_{i}+\left(m_{\text {load }}-m_{\text {unload }}\right) \cdot t_{\text {int }}
$$

where $m_{i+1}$ and $m_{i}$ are the thermal storage fluid masses in the hot tank before and after the time interval, respectively; $m_{\text {load }}$ and $m_{\text {unload }}$ are the inlet and outlet mass 
flows of the hot tank during the time interval; and $t_{\text {int }}$ is the time interval.

The energy balance during the interval time is calculated as

$$
H_{i+1}=\left(m_{i} \cdot h_{i}+m_{\text {load }} \cdot h_{\text {load }} \cdot t_{\text {int }}-m_{\text {unload }} \cdot h_{\text {unload }} \cdot t_{\text {int }}\right)-Q_{\text {loss }}
$$

where $h_{i}$ and $h_{\text {load }}$ are the specific enthalpy of the fluid in the hot tank and into the hot tank, respectively; $h_{\text {unload }}$ is the specific enthalpy of fluid flows out the hot tank; $Q_{\text {loss }}$ is the heat loss in the hot tank, which is calculated as

$$
Q_{\text {loss }, T E S}=k_{\text {loss }}\left(\left(T_{i}+T_{i+1}\right) / 2-T_{a m b}\right) \cdot t_{\text {int }}
$$

where $k_{\text {loss }}$ is the specific heat loss coefficient; $T_{i}$ and $T_{i+1}$ are the temperatures of fluid in the hot tank before and after the time interval, respectively.

\subsection{Thermodynamic index}

The solar exergy percentages in a STPG are calculated as:

$$
\begin{aligned}
& \lambda_{e x, s t}=\frac{E x_{r s, s}}{E x_{b o i l e r}+E x_{r s, s}+E x_{f w, s}} \\
& \lambda_{e x, s p}=\frac{E x_{f w, s}}{E x_{b o i l e r}+E x_{r s, s}+E x_{f w, s}}
\end{aligned}
$$

where $\lambda_{\text {ex,st }}$ and $\lambda_{\text {ex,sp }}$ are the solar exergy percentages of the solar tower and parabolic troughs, respectively; Ex $x_{\text {boiler }}$ is the exergy absorbed in boiler, $\mathrm{MW}_{\text {th }}$; $E x_{r s, s}$ and $E x_{f w, s}$ are the exergy absorbed by extracted reheat steam and extracted feed-water, $\mathrm{MW}_{\mathrm{th}}$, respectively.

This is different from a SPCG or STCG that integrates solar energy with individual preheaters or the boiler. The present system employs solar energy in a different heating process, preheating of feed-water and reheating of steam. Operating this integrates system is more flexible than a SPCG or STCG due to the different sources of required energy and the effects of the energy introduced. Therefore, the power produced by solar 
energy in a STPG cannot be directly evaluated from the comparison of power output at the same coal consumption condition. In this study, the individual contribution of solar energy is identified according to the solar exergy percentage in each power generation section:

$$
\begin{gathered}
P_{s t}=\frac{E x_{r s, s} \cdot \eta_{g}}{E x_{r s, s}+E x_{r s, b}+E x_{r s, c}}\left\{P_{I P}+P_{L P}+\frac{\sum_{i=3}^{8} E x_{f w, i}}{E x_{f w}+E x_{m s, b}}\left[P_{H P}+\frac{E x_{r s, c}\left(P_{I P}+P_{L P}\right)}{E x_{r s, s}+E x_{r s, b}+E x_{r s, c}}\right]\right\} \\
P_{s p}=\frac{E x_{f w, s} \cdot \eta_{g}}{E x_{f w}+E x_{m s, b}}\left(1+\frac{\sum_{i=1}^{8} E x_{f w, i}}{E x_{f w}+E x_{m s, b}}\right)\left[P_{H P}+\frac{E x_{r s, c}\left(P_{I P}+P_{L P}\right)}{E x_{r s, s}+E x_{r s, b}+E x_{r s, c}}\right]
\end{gathered}
$$

where $P_{s t}$ and $P_{s p}$ are the power output from the solar tower energy and parabolic troughs energy, $\mathrm{MW}$, respectively; $P_{H P}, P_{I P}$ and $P_{L P}$ are the mechanical power generated in high-pressure cylinder, intermediate-pressure cylinder and low-pressure cylinder of the turbine, respectively; $E x_{m s, b}$ and $E x_{r s, b}$ are the exergy absorbed by main steam and reheat steam in boiler, $\mathrm{MW}_{\mathrm{th}} ; E x_{f w}$ and $E x_{r s, c}$ are the exergy of feed-water before entering the boiler and the cold reheat steam, $\mathrm{MW}_{\mathrm{th}} ; E x_{f w, i}$ is the exergy absorbed by feed-water in the $i_{t h}$ preheater and $E x_{f w, s}$ is the solar exergy absorbed by feed-water, $\mathrm{MW}_{\mathrm{th}} ; \eta_{g}$ is the generator efficiency.

In heliostat field, the minimum DNI for activation of the tracking system is 150 $\mathrm{W} / \mathrm{m}^{2}$ and the minimum solar altitude angle is $15^{\circ}$ [40], thus, the solar tower power generation efficiency is:

$$
\eta_{s t}=\frac{P_{s t}}{Q_{s t}}=\frac{P_{s t}}{\int_{t \mid D N I>150, \alpha>15^{\circ}} A_{f} \cdot D N I \cdot n d t}
$$

The solar parabolic trough power generation efficiency is:

$$
\eta_{s p}=\frac{P_{s p}}{Q_{s p}}=\frac{P_{s p}}{\int_{t \mid Q_{c o l, e f f}>0} A_{n e t} \cdot D N I d t}
$$

The system power generation efficiency is calculated as:

$$
\eta_{S T P G}=\frac{P_{S T P G}}{Q_{c o a l}+Q_{s t}+Q_{s p}}
$$


where $P_{S T P G}$ is the power output from the integrated system, $\mathrm{MW}_{\mathrm{e}} ; Q_{s t}$ and $Q_{s p}$ are the effective incident solar energy for heliostats and parabolic troughs, $\mathrm{MW}_{\text {th }}$, respectively. $Q_{\text {coal }}$ is the thermal energy provided by coal fuel, $\mathrm{MW}_{\text {th }}$.

The standard coal consumption rate is calculated as:

$$
b_{S t}=\frac{Q_{\text {coal }} \cdot 3.6 \times 10^{6}}{P_{S T P G} \cdot L H V_{s t}}
$$

where $L H V_{s t}$ is the low heating value of standard coal fuel, $29310 \mathrm{~kJ} / \mathrm{kg}$.

The overall exergy efficiency of the system is calculated as:

$$
\eta_{e x}=\frac{P_{S T P G}}{E x_{c o a l}+E x_{s t}+E x_{s p}}
$$

where $E x_{s t}$ and $E x_{s p}$ are the effective incident solar exergy for heliostats and parabolic troughs, MW, respectively. Ex $x_{\text {coal }}$ is the exergy provided by coal fuel, MW. The calculation of solar exergy and coal exergy is described in previous study [28].

\section{Case studies}

\subsection{Basic data}

The DNI values in four selected days in a typical meteorological year (TMY), the vernal equinox, summer solstice, autumnal equinox and winter solstice are shown in Figure 4 [41]. The heliostat field is assumed to be arranged in radial staggered layout and with three zones to improve the shadowing and blocking factor. The mirror from the GEMASOLAR power plant is considered in this study [42, 43]. The parabolic troughs are arranged in several loops of LS-2 collectors with the row spacing of 17.3 $\mathrm{m}$. The three-tank structure is configurated for TES system, with inlet temperatures of $320{ }^{\circ} \mathrm{C}, 390{ }^{\circ} \mathrm{C}$ and $580{ }^{\circ} \mathrm{C}$. The parameters of the heliostat field and parabolic troughs are shown in Table 1 . The boiler in this study is a $600 \mathrm{MW}_{\mathrm{e}}$ supercritical pressure once- 
through boiler with single furnace. The bituminous coal with LHV of $21,981 \mathrm{~kJ} / \mathrm{kg}$ is used as the fuel. The turbine is N600-24.2/566/566 type with a condenser pressure of $4.9 \mathrm{kPa}$. The main parameters of the turbine, the heating surfaces area and the coal composition are shown in Table 2.

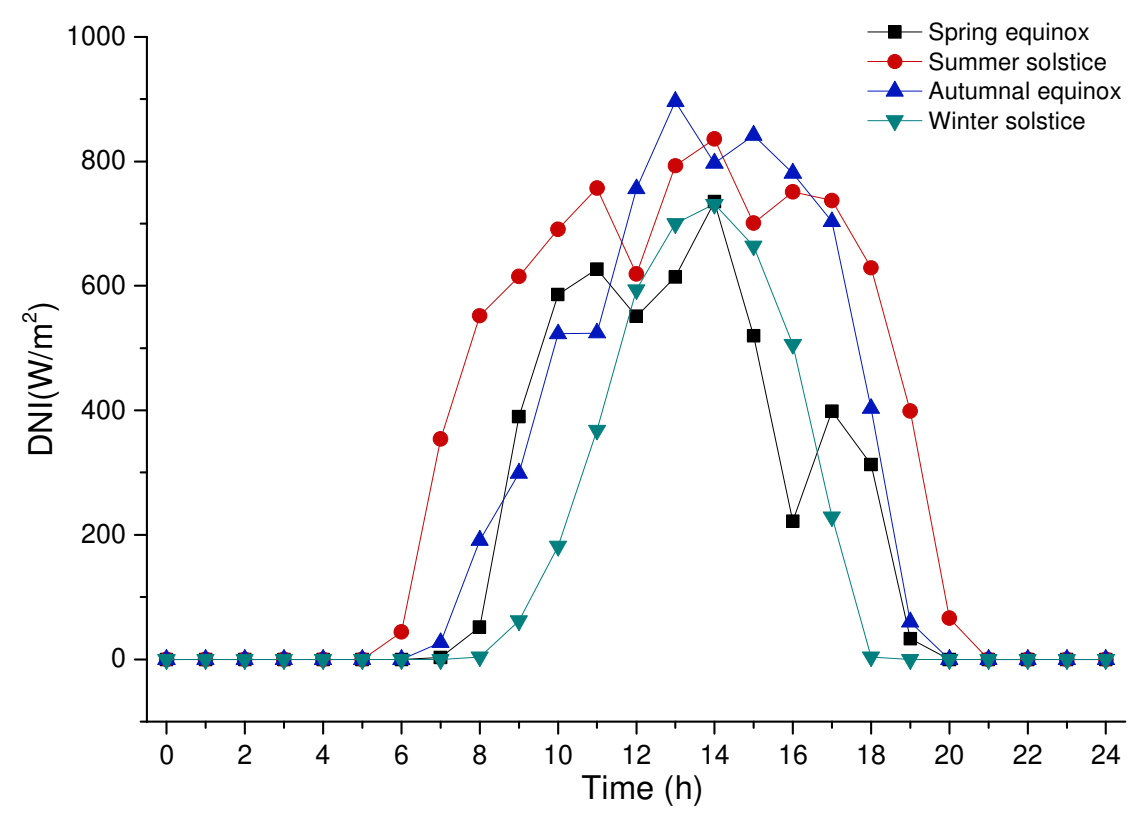

Figure 4. Hourly DNI distribution in vernal equinox, summer solstice, autumnal equinox and winter solstice of TMY.

Table 1. Main input parameters of the heliostat field and parabolic troughs

\begin{tabular}{llll}
\hline Parameter & Value & Unit & Reference \\
\hline Latitude & $37.37 \mathrm{~N}$ & $\circ$ & {$[41]$} \\
Longitude & $97.37 \mathrm{E}$ & $\circ$ & {$[41]$} \\
Annual DNI & 1543.64 & $\mathrm{kWh} / \mathrm{m}^{2} / \mathrm{year}$ & {$[41]$} \\
\hline Heliostat number & $46 \times 8+92 \times 11+184 \times 20$ & - & {$[42]$} \\
Heliostat size & $12.305 \times 9.752$ & $\mathrm{~m}^{2}$ & {$[39]$} \\
Heliostat field layout & radial staggered layout & & {$[43]$} \\
Standard deviation surface error & 0.94 & $\mathrm{mrad}$ & {$[39]$} \\
Standard deviation tracking error & 0.63 & $\mathrm{mrad}$ & {$[39]$} \\
Standard deviation of sun shape & 2.51 & $\mathrm{mrad}$ & {$[39]$} \\
Effective reflectivity & $0.88 \times 0.95$ & - & {$[39]$} \\
Receiver optical efficiency & 0.93 & - & {$[44]$} \\
Receiver surface emissivity & 0.88 & - & {$[44]$} \\
\hline Aperture width of trough & 5.77 & $\mathrm{~m}$ & {$[45]$} \\
Gross length of one trough unit & 576 & $\mathrm{~m}$ & {$[45]$} \\
\hline
\end{tabular}




\begin{tabular}{llll}
\hline Total net aperture area & 345882.1 & $\mathrm{~m}^{2}$ & \\
Optical active portion of aperture & 0.9461 & - & {$[45]$} \\
Peak optical efficiency & 0.734 & - & {$[45]$} \\
Row spacing & 17.3 & $\mathrm{~m}$ & {$[45]$} \\
Molten salt hot tank 1 temperature & 580 & ${ }^{\circ} \mathrm{C}$ & \\
Molten salt hot tank 2 temperature & 390 & ${ }^{\circ} \mathrm{C}$ & \\
Cold tank temperature & 320 & ${ }^{\circ} \mathrm{C}$ & \\
TES capacity & 14166 & tonne & \\
\hline
\end{tabular}

Table 2. Main input parameters of the power block

\begin{tabular}{|c|c|c|c|c|c|c|}
\hline \multicolumn{3}{|c|}{ Parameters } & $100 \%$ & $75 \%$ & $50 \%$ & Unit \\
\hline \multicolumn{3}{|c|}{ Power output } & 600 & 450 & 300 & MWe \\
\hline \multicolumn{3}{|c|}{ Feed-water temperature } & 276.3 & 257.7 & 235.3 & ${ }^{\circ} \mathrm{C}$ \\
\hline \multicolumn{3}{|c|}{ Main steam temperature } & 566.0 & 561.0 & 545.0 & ${ }^{\circ} \mathrm{C}$ \\
\hline \multicolumn{3}{|c|}{ Main steam mass flow rate } & 467.5 & 342.2 & 227.3 & $\mathrm{~kg} / \mathrm{s}$ \\
\hline \multicolumn{3}{|c|}{ Reheat steam temperature } & 566.0 & 555.0 & 555.0 & ${ }^{\circ} \mathrm{C}$ \\
\hline \multicolumn{3}{|c|}{ Reheat steam mass flow rate } & 399.6 & 297.6 & 201.6 & $\mathrm{~kg} / \mathrm{s}$ \\
\hline \multicolumn{3}{|c|}{ Condenser pressure } & 4.9 & 4.9 & 4.9 & $\mathrm{kPa}$ \\
\hline Material & Fraction & Unit & \multicolumn{2}{|c|}{ Heating surface } & Area & Unit \\
\hline$C_{a r}$ & 57.5 & $\%$ & \multicolumn{2}{|c|}{ FSH-2 } & 2549 & $\mathrm{~m}^{2}$ \\
\hline$H_{a r}$ & 3.11 & $\%$ & \multicolumn{2}{|l|}{ FSH-1 } & 1882 & $\mathrm{~m}^{2}$ \\
\hline$O_{a r}$ & 2.78 & $\%$ & \multicolumn{2}{|l|}{$\mathrm{RSH}$} & 1425 & $\mathrm{~m}^{2}$ \\
\hline$N_{a r}$ & 0.99 & $\%$ & \multicolumn{2}{|l|}{ PSH } & 1386 & $\mathrm{~m}^{2}$ \\
\hline$S t_{a r}$ & 2.0 & $\%$ & \multicolumn{2}{|l|}{ FRH } & 2443 & $\mathrm{~m}^{2}$ \\
\hline$A_{a r}$ & 23.72 & $\%$ & \multicolumn{2}{|l|}{ LRH-V } & 1518 & $\mathrm{~m}^{2}$ \\
\hline$M_{a r}$ & 9.9 & $\%$ & \multicolumn{2}{|l|}{ LRH-H } & 10683 & $\mathrm{~m}^{2}$ \\
\hline LHV & 21981 & $\mathrm{~kJ} / \mathrm{kg}$ & \multicolumn{2}{|l|}{ ECON } & 17590 & $\mathrm{~m}^{2}$ \\
\hline
\end{tabular}

\subsection{Results and discussion}

In this section, the STPG system is simulated in $100 \%, 75 \%$ and $50 \%$ load. The parameters of working fluid in each heat exchanger of the boiler and regenerative system are presented and validated in comparison with design data of the practical 600 $\mathrm{MW}_{\mathrm{e}}$ power plant under three different loads. The variation of system performance concerning the integrated solar energy from solar tower and parabolic troughs are observed to illustrate the effects of solar energy absorbed by reheat steam and feed- 
water are explored. Then the variation of system performance under off-design loads are explored. In the end, simulation for four typical days were performed to illustrate the system performance during a specific time under different solar irradiation conditions and power loads.

The calculation of the heliostat field is coded in MATLAB and the simulation of the supercritical coal-fired power plant is performed in Ebsilon Professional. The comparison of the simulation and design values of the boiler in $100 \%, 75 \%$ and $50 \%$ load are shown in Table 3. The comparison of simulation and design values of the regenerative system is shown in Table 4 . These comparisons show high consistency and reliability.

Table 3. The comparison of simulation and design values of the boiler under 100\%, 75\% and 50\%

load

\begin{tabular}{|c|c|c|c|c|c|c|}
\hline \multirow[b]{2}{*}{ Parameters } & \multicolumn{2}{|c|}{$\begin{array}{l}\text { Working fluid inlet } \\
\text { temperature }\left({ }^{\circ} \mathrm{C}\right)\end{array}$} & \multicolumn{2}{|c|}{$\begin{array}{l}\text { Working fluid outlet } \\
\text { temperature }\left({ }^{\circ} \mathrm{C}\right)\end{array}$} & \multirow{2}{*}{$\begin{array}{c}\text { Heat } \\
(\mathrm{GJ} / \mathrm{h}) \\
\text { Design }\end{array}$} & \multirow{2}{*}{$\begin{array}{l}\text { absorption } \\
\text { Simulation }\end{array}$} \\
\hline & Design & Simulation & Design & Simulation & & \\
\hline \multicolumn{7}{|l|}{$100 \%$ load } \\
\hline FSH-2 & 530 & 530.1 & 571 & 571.2 & 223.4 & 223.0 \\
\hline FSH-1 & 504 & 504.3 & 530 & 530.1 & 161.1 & 161.4 \\
\hline RSH & 460 & 459.8 & 512 & 512.2 & 360.6 & 361.9 \\
\hline PSH & 428 & 427.6 & 470 & 469.7 & 394.0 & 395.9 \\
\hline Waterwall & 330 & 330.0 & 417 & 417.1 & 1805.0 & 1806.4 \\
\hline ECON & 274 & 274.0 & 330 & 330.0 & 467.0 & 467.3 \\
\hline FRH & 468 & 468.1 & 567 & 567.1 & 315.0 & 315.1 \\
\hline LRH-V & 442 & 442.1 & 468 & 468.1 & 83.6 & 83.4 \\
\hline LRH-H & 300 & 300.0 & 442 & 442.1 & 489.3 & 489.6 \\
\hline \multicolumn{7}{|l|}{$75 \%$ load } \\
\hline FSH-2 & 529 & 529.4 & 571 & 571.5 & 163.8 & 164.9 \\
\hline FSH-1 & 501 & 502.7 & 529 & 529.4 & 119.0 & 116.7 \\
\hline RSH & 454 & 454.7 & 510 & 510.7 & 278.0 & 272.1 \\
\hline PSH & 419 & 419.4 & 465 & 465.3 & 306.4 & 306.7 \\
\hline Waterwall & 320 & 319.4 & 408 & 405.9 & 1333.6 & 1334.9 \\
\hline ECON & 255 & 255.0 & 320 & 319.4 & 377.4 & 376.5 \\
\hline
\end{tabular}




\begin{tabular}{lllllll}
\hline FRH & 467 & 467.3 & 569 & 569.5 & 237.4 & 235.4 \\
LRH-V & 439 & 440.0 & 467 & 467.3 & 63.2 & 63.3 \\
LRH-H & 282 & 282.0 & 439 & 440.0 & 383.8 & 385.1 \\
\hline $\mathbf{5 0 \%}$ load & & & & & & \\
FSH-2 & 526 & 526.4 & 571 & 571.6 & 96.8 & 96.4 \\
FSH-1 & 495 & 497.4 & 526 & 526.4 & 70.8 & 70.2 \\
RSH & 425 & 426.1 & 504 & 505.5 & 201.3 & 199.7 \\
PSH & 376 & 376.1 & 443 & 443.8 & 220.4 & 218.6 \\
Waterwall & 301 & 301.0 & 360 & 359.8 & 990.5 & 991.4 \\
ECON & 232 & 232.0 & 301 & 301.0 & 257.0 & 258.1 \\
FRH & 466 & 467.0 & 569 & 569.1 & 156.7 & 155.2 \\
LRH-V & 441 & 441.5 & 466 & 467.0 & 38.2 & 38.5 \\
LRH-H & 291 & 291.0 & 441 & 441.5 & 230.1 & 230.8 \\
\hline
\end{tabular}

Table 4. The comparison of simulation and design values of the turbine under 100\%, $75 \%$ and $50 \%$ load

\begin{tabular}{llllll}
\hline & & \multicolumn{2}{l}{ Enthalpy $(\mathrm{kJ} / \mathrm{kg})$} & \multicolumn{2}{l}{ Mass flow rate $(\mathrm{t} / \mathrm{h})$} \\
\cline { 3 - 6 } Parameter & Pressure $(\mathrm{MPa})$ & Design & Simulation & Design & Simulation \\
\hline 100\% load & & & & & \\
Main steam & 24.2 & 3398.8 & 3398.8 & 1683.91 & 1683.9 \\
1st extraction & 6.1 & 3068.2 & 3068.2 & 95.84 & 95.9 \\
2nd extraction & 4.311 & 2988.7 & 2988.8 & 118.41 & 118.2 \\
Hot reheat steam & 3.88 & 3597.9 & 3597.9 & 1438.5 & 1438.5 \\
3rd extraction & 2.16 & 3413.4 & 3412.4 & 71.4 & 71.1 \\
4th extraction & 1,054 & 3201.3 & 3200.4 & 68.46 & 68.0 \\
5th extraction & 0.465 & 3002.5 & 3002.2 & 93.31 & 93.4 \\
6th extraction & 0.125 & 2755.7 & 2755.5 & 42.12 & 42.0 \\
7th extraction & 0.06 & 2635.6 & 2635.4 & 52.38 & 52.4 \\
8th extraction & 0.0204 & 2492.1 & 2491.9 & 45.49 & 45.6 \\
Exhaust steam & 0.0049 & 2331.7 & 2331.5 & 988.98 & 989.7 \\
\hline 75\% load & & & & & \\
Main steam & 19.1 & 3435.4 & 3438.0 & 1231.9 & 1231.9 \\
1st extraction & 4.53 & 3088.1 & 3088.1 & 61.44 & 61.1 \\
2nd extraction & 3.203 & 3007.1 & 3007.0 & 76.31 & 75.4 \\
Hot reheat steam & 2.883 & 3580.5 & 3582.0 & 1071.32 & 1071.3 \\
3rd extraction & 1.61 & 3398.5 & 3399.5 & 51.13 & 50.5 \\
4th extraction & 0.791 & 3190 & 3190.9 & 52.31 & 52.4 \\
5th extraction & 0.323 & 2976.7 & 2977.1 & 60.57 & 60.3 \\
6th extraction & 0.094 & 2739.6 & 2740.3 & 29.42 & 29.4 \\
7th extraction & 0.046 & 2623.7 & 2624.3 & 37.47 & 37.4 \\
8th extraction & 0.0158 & 2478.3 & 2478.9 & 26.82 & 26.5 \\
\hline
\end{tabular}




\begin{tabular}{llllll}
\hline Exhaust steam & 0.0049 & 2347 & 2347.7 & 774.54 & 771.6 \\
\hline 50\% load & & & & & \\
Main steam & 12.7 & 3459.5 & 3461.4 & 818.33 & 818.3 \\
1st extraction & 3.08 & 3109.9 & 3109.5 & 34.47 & 34.3 \\
2nd extraction & 2.185 & 3018.1 & 3032.3 & 43.01 & 42.3 \\
Hot reheat steam & 1.967 & 3589.1 & 3590.3 & 725.61 & 725.6 \\
3rd extraction & 1.11 & 3408.4 & 3409.1 & 31.36 & 30.3 \\
4th extraction & 0.554 & 3203.5 & 3204.1 & 31.89 & 31.9 \\
5th extraction & 0.23 & 2991.1 & 2991.5 & 38.55 & 38.4 \\
6th extraction & 0.066 & 2749 & 2749.4 & 18.77 & 18.7 \\
7th extraction & 0.032 & 2631 & 2631.4 & 23.67 & 23.5 \\
8th extraction & 0.0113 & 2487.8 & 2488.2 & 11.54 & 11.5 \\
Exhaust steam & 0.0049 & 2405.7 & 2405.8 & 553.83 & 552.2 \\
\hline
\end{tabular}

\subsubsection{Effects of introduced solar energy}

Table 5 shows the variation of maximum absorbed solar energy by reheat steam and system performance with $0,50 \%$ and $100 \%$ feed-water extraction from $\mathrm{PH} 1$, under different loads. From the table, with the constant temperatures of superheat steam and reheat steam, the increase of feedwater extraction results in the growth of maximum reheat steam extraction percentage and the maximum solar energy can be introduced into reheat steam. The maximum reheat steam extraction percentage increases by $7.4 \%$, which is from $140 \mathrm{~kg} / \mathrm{s}$ to $180 \mathrm{~kg} / \mathrm{s}$ when the feedwater extraction increases from $0 \%$ to $100 \%$ under $100 \%$ load. The absorbed solar energy by reheat steam increases from 89.0 $\mathrm{MW}_{\text {th }}$ to $109.2 \mathrm{MW}_{\text {th. }}$ For $75 \%$ and $50 \%$ load conditions, the maximum solar energy introduction into reheat steam increases from $57.3 \mathrm{MW}_{\text {th }}$ to $68.7 \mathrm{MW}_{\text {th }}$ and from 39.0 $\mathrm{MW}_{\text {th }}$ to $44.5 \mathrm{MW}_{\text {th }}$ when feed-water extraction percentage from $\mathrm{PH} 1$ increases from 0 to $100 \%$.

That is because, as the solar energy from parabolic troughs introduced and feedwater extracted, the required steam extraction from HP to preheat the feed-water 
decreases. This leads to the increase of reheat steam mass flow, which results in opposite effects of the reheat steam extraction. Therefore, the effects of extraction from reheat steam on the heat exchange processes in the boiler are partly counteracted by feed-water extraction and lead to a wider range to integrate solar energy in safety limits. As a result, the maximum solar tower power generation is enhanced from $39.3 \mathrm{MW}_{\mathrm{e}}$ to 50.4 $\mathrm{MW}_{\mathrm{e}}$, from 26.6 $\mathrm{MW}_{\mathrm{e}}$ to $31.8 \mathrm{MW}_{\mathrm{e}}$ and from 17.9 $\mathrm{MW}_{\mathrm{e}}$ to $20.4 \mathrm{MW}_{\mathrm{e}}$ as the extracted feed-water increases under three loads. The standard coal saved rate increases from $18.8 \mathrm{~g} / \mathrm{kWh}$ to $32.0 \mathrm{~g} / \mathrm{kWh}$ and $\mathrm{CO}_{2}$ emissions decrease from $701.4 \mathrm{~g} / \mathrm{kWh}$ to $665.1 \mathrm{~g} / \mathrm{kWh}$ under $100 \%$ load because of increase in absorbed solar energy input into the system. Under $75 \%$ and $50 \%$ load, the standard coal saved rate increases from 17.3 $\mathrm{g} / \mathrm{kWh}$ to $27.9 \mathrm{~g} / \mathrm{kWh}$ and from $16.5 \mathrm{~g} / \mathrm{kWh}$ to $25.5 \mathrm{~g} / \mathrm{kWh}$ while $\mathrm{CO}_{2}$ emissions decreased from $721.1 \mathrm{~g} / \mathrm{kWh}$ to $692.0 \mathrm{~g} / \mathrm{kWh}$ and from $752.0 \mathrm{~g} / \mathrm{kWh}$ to $727.5 \mathrm{~g} / \mathrm{kWh}$, respectively.

Table 5. System performance with different feed-water extraction from PH1 under three loads

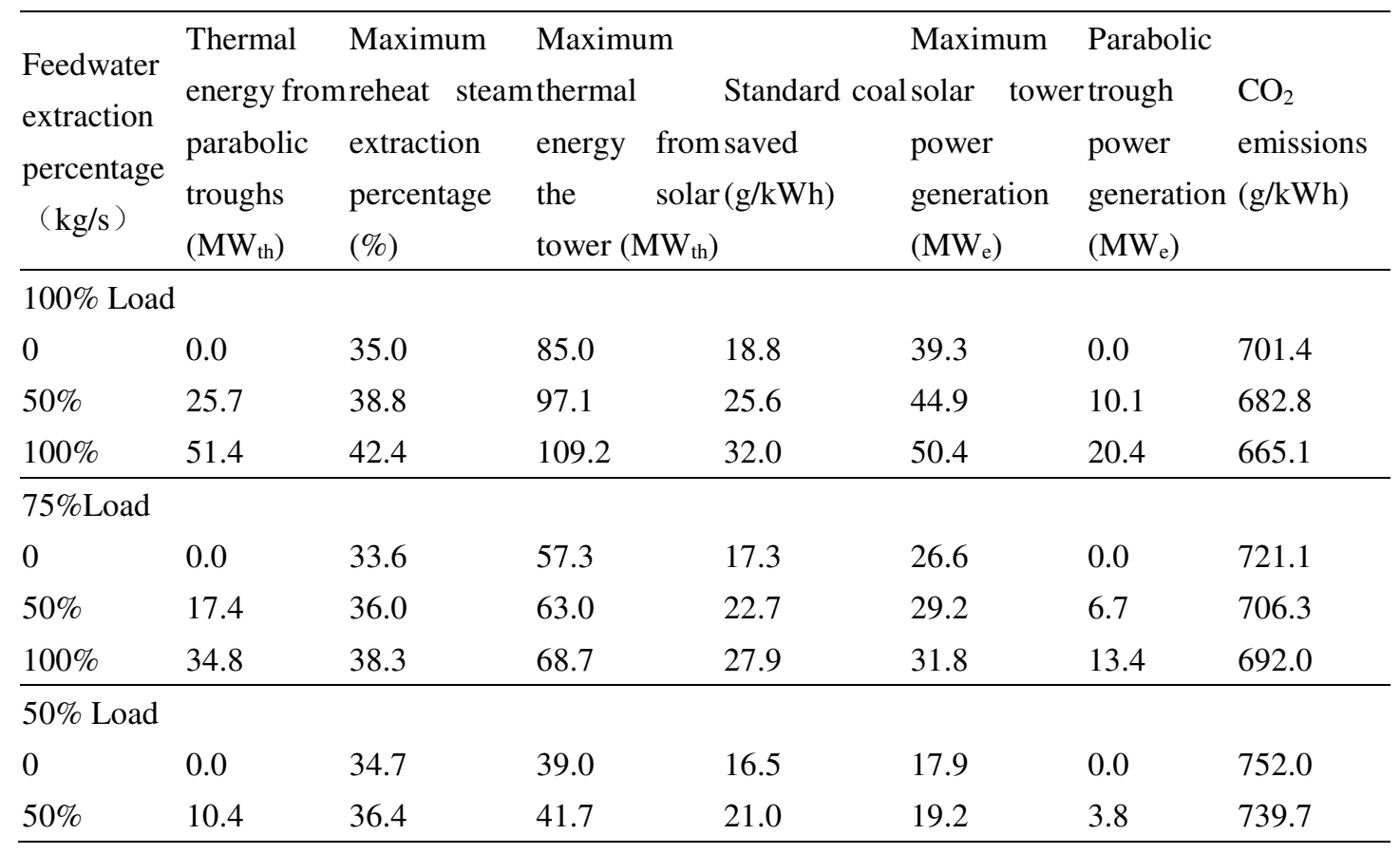




\begin{tabular}{llllllll}
\hline $100 \%$ & 20.7 & 38.0 & 44.5 & 25.5 & 20.4 & 7.5 & 727.5 \\
\hline
\end{tabular}

The effects of introduced parabolic trough and solar tower energy in $100 \%$ load scenario are illustrated as an example. The variation of solar tower exergy percentage $\lambda_{s t}$, parabolic troughs exergy percentage $\lambda_{s p}$ and standard coal consumption rate $b_{s t}$ concerning the extraction of reheat steam and feed-water under $100 \%$ load are represented in Figure 5. The $\lambda_{s t}$ and $\lambda_{s p}$ are used to illustrate the proportion of solar exergy in energy sources. Higher exergy percentage means more solar energy can be utilised and indicates a higher limit for introduced solar energy. The $b_{s t}$ is used to directly reflect the system performance and fuel-saving effects due to the increase of introduced solar energy. From the figure, the introduced solar energy from parabolic troughs and solar tower both result in the decrease of coal consumption. Without feedwater extracted from PH1, the $\lambda_{s t}$ increases from 0 to $6.8 \%$ as reheat steam extraction increases from 0 to $140 \mathrm{~kg} / \mathrm{s}$, at the maximum extraction percentage of $35.0 \%$. The $b_{s t}$ declines from $273.8 \mathrm{~g} / \mathrm{kWh}$ to $255.0 \mathrm{~g} / \mathrm{kWh}$. When $100 \%$ feed-water is extracted, the solar exergy percentage almost doubles to $11.7 \%$, of which the $\lambda_{s p}$ slightly drops at $3.2 \%$ and $\lambda_{s t}$ reaches $8.4 \%$ as extracted reheat steam increases to $180 \mathrm{~kg} / \mathrm{s}$. As a result, the lowest $b_{s t}$ decreases from $255.0 \mathrm{~g} / \mathrm{kWh}$ to $241.8 \mathrm{~g} / \mathrm{kWh}$. 


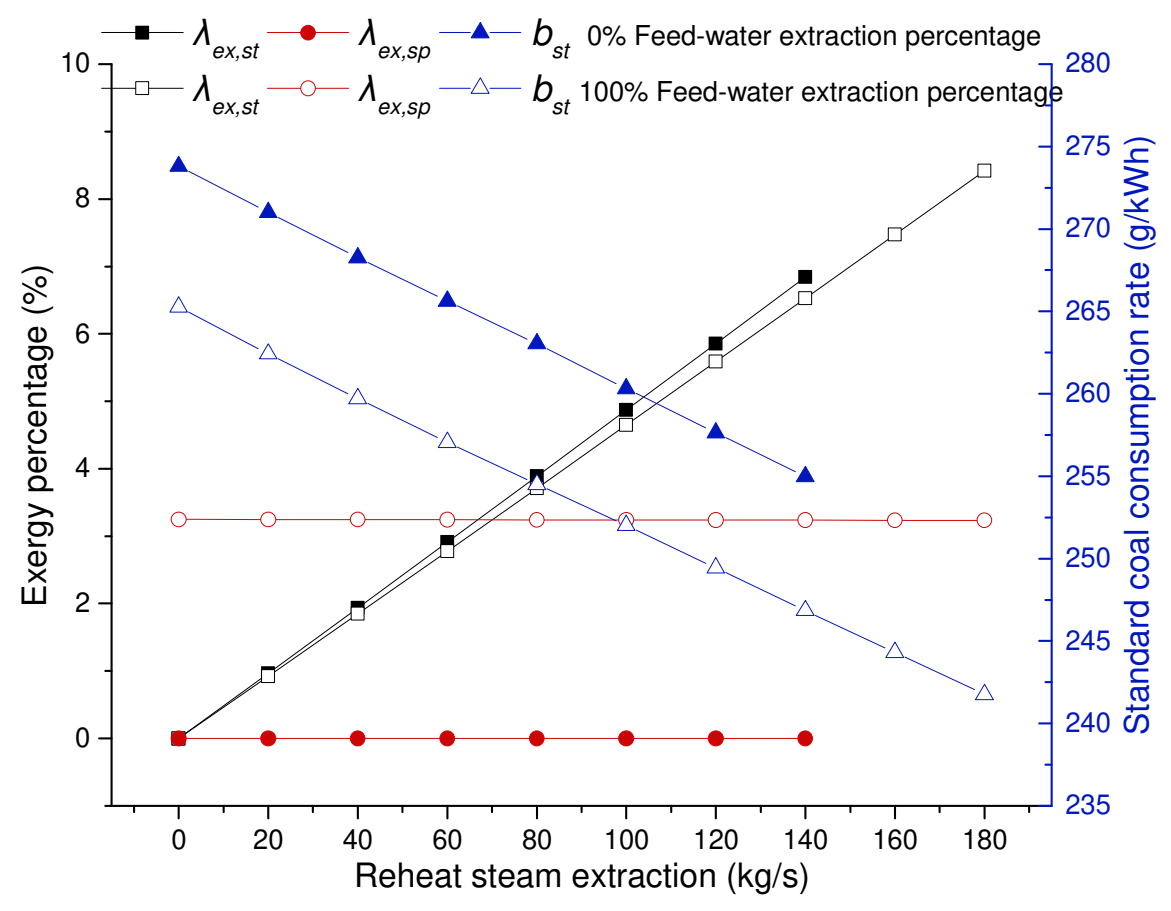

Figure 5. The variation of solar exergy percentage and standard coal consumption rate

Figure 6 shows the variation of power generation from the solar tower and parabolic troughs $\left(P_{s t}, P_{s p}\right)$ and solar power efficiency $\eta_{\text {solar }}$ concerning the extraction of reheat steam and feed-water. Power generation from the solar tower and parabolic troughs is distinguished to present the contribution of different sources of energy, which is also used to calculate the solar power efficiency. From the figure, $\eta_{\text {solar }}$ tends to be improved as solar energy introduced into reheat steam increased and declines as extracted feed-water increases. Without feed-water extracted, $P_{s t}$ can increase to $39.3 \mathrm{MW}_{\mathrm{e}}$ and $\eta_{\text {solar }}$ slightly grows from $21.4 \%$ to $21.8 \%$ as reheat steam extraction rises because of the increasing proportion of solar tower energy which is relatively more effective in using solar energy to produce power than the feed-water extraction. When $100 \%$ feed-water is extracted, $70.8 \mathrm{MW}_{\mathrm{e}}$ solar power generation can be achieved, of which $50.4 \mathrm{MW}_{\mathrm{e}}$ comes from solar power and $\eta_{\text {solar }}$ boosts from $18.5 \%$ to $20.8 \%$ as extracted reheat steam rises. 


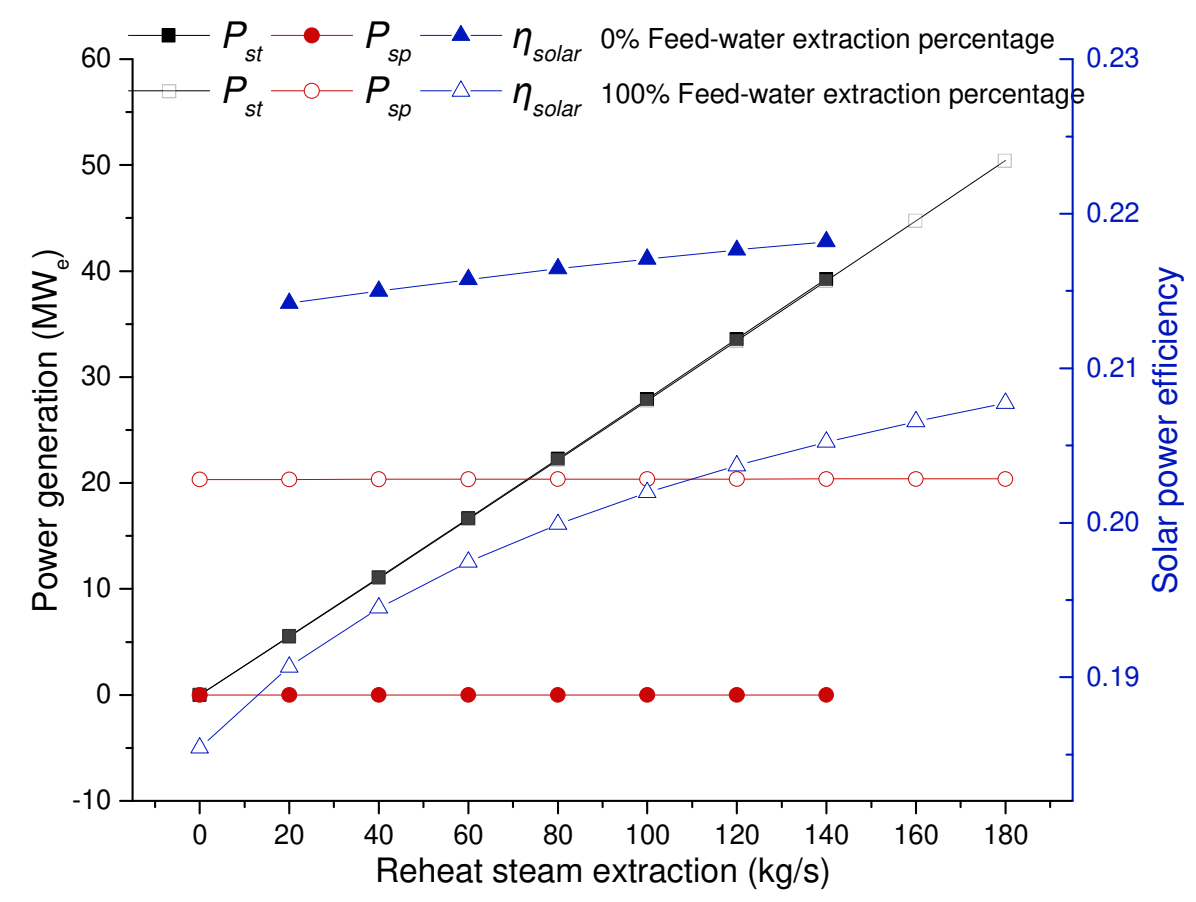

Figure 6. The variation of solar power output and solar power efficiency with respect to the feed-water and reheat steam extraction

Figure 7 presents the effects of extracted reheat steam and feed-water on system efficiency, boiler efficiency and saved $\mathrm{CO}_{2}$ emissions under $100 \%$ load. From the figure, $\eta_{S T P G}$ tends to decrease as the introduced solar energy increases, while $\eta_{\text {boiler }}$ performs differently according to the feed-water extraction. The overall exergy efficiency varies from $42.7 \%$ to $40.7 \%$ as solar energy introduced into reheat steam increased at $0 \%$ feed-water extraction percentage and varies from $41.1 \%$ to $38.9 \%$ at $100 \%$ feed-water extraction percentage. Without feed-water extracted, $\eta_{\text {boiler }}$ continues to decline from $94.5 \%$ to $94.1 \%$ and $\eta_{S T P G}$ gradually decreases from $44.9 \%$ to $42.1 \%$ as the increasing of reheat steam extraction. When $100 \%$ feed-water is extracted from PH1, the $\eta_{\text {boiler }}$ shows a short improvement at $94.4 \%$ as extracted reheat steam raises from 0 to $20 \mathrm{~kg} / \mathrm{s}$, and then drops to $94.1 \%$ as extracted reheat steam increases to $160 \mathrm{~kg} / \mathrm{s}$. The slight delay of boiler performance deterioration is because 
the effects of extraction from feed-water leads to the growth of reheat steam mass flow, diminishing the effects of reheat steam extraction. Despite the decreases of STPG and boiler performance, the saved $\mathrm{CO}_{2}$ emissions reach $51.8 \mathrm{~g} / \mathrm{kWh}$ at $0 \%$ feed-water extraction scenario and increases from $23.5 \mathrm{~g} / \mathrm{kWh}$ to $88.2 \mathrm{~g} / \mathrm{kWh}$ at $100 \%$ feed-water extraction scenario.

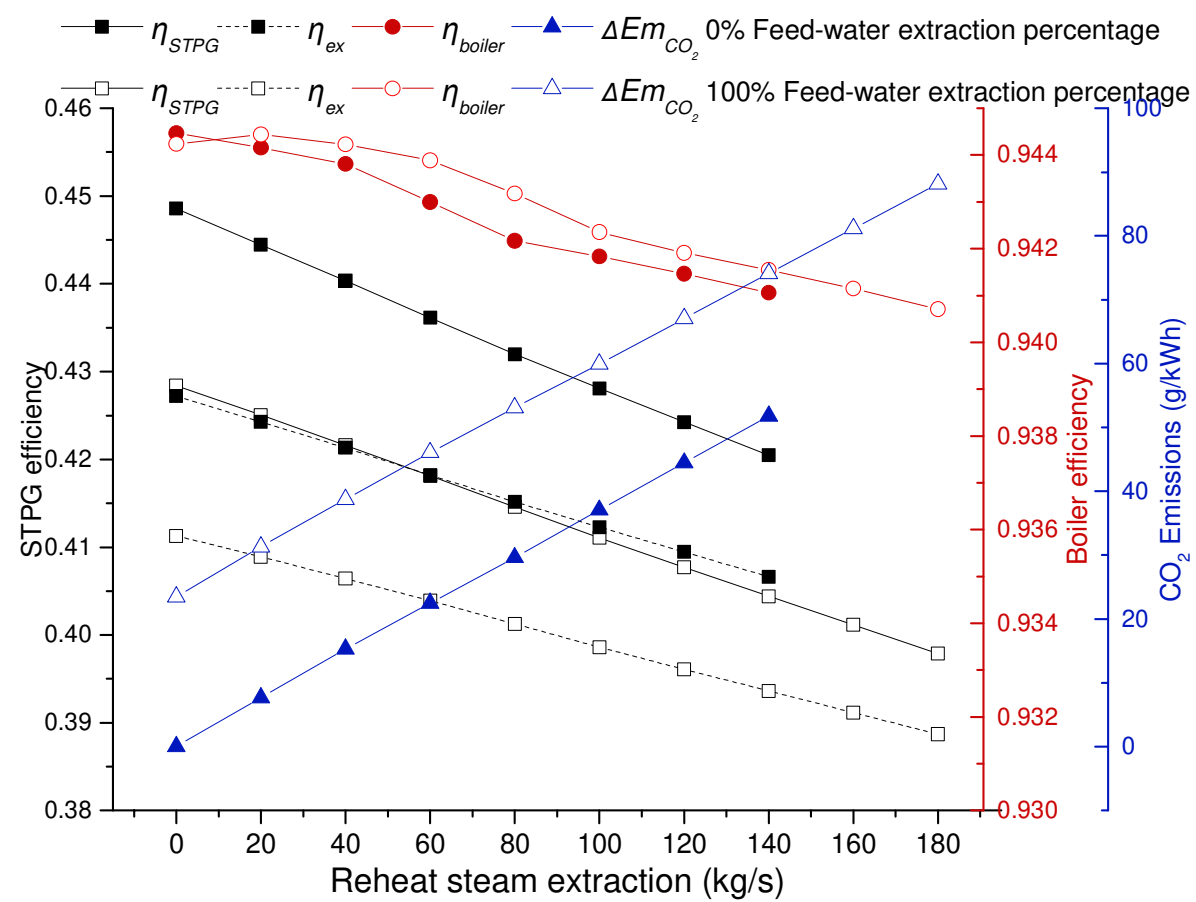

Figure 7. The variation of STPG efficiency, boiler efficiency and saved $\mathrm{CO}_{2}$ emissions with respect to the feed-water and reheat steam extraction

\subsubsection{Off-design performances}

In practical operation, the power load of a plant is determined from the power grid, which means the plant can't produce the designed power and needs to generate in offdesign mode most of the time. For a STPG system, the part-load power output combining the variation of integrated solar energy, including the operation of the heliostat field, receiver, parabolic troughs, TES system, boiler and the regenerative system, extraction from reheat steam and feed-water, could significantly affect the 
performance of the boiler and the overall power generation process, which needs to be explored in detail. Therefore, this study investigates the off-design performance characteristics of the selected scheme.

The system performance under $100 \%, 75 \%$ and $50 \%$ loads are explored in this section. Figure 8 shows the variation of solar exergy percentage and standard coal consumption rate under three loads, with PH1 fully replaced. As extracted reheat steam increases, the solar exergy percentage increases from $3.3 \%$ to $11.7 \%$ and standard coal consumption rate drops from $265.3 \mathrm{~g} / \mathrm{kWh}$ to $241.8 \mathrm{~g} / \mathrm{kWh}$ under $100 \%$ load. Under $75 \%$ and $50 \%$ load, maximum solar exergy percentages are $9.9 \%$ and $9.3 \%$, respectively. Correspondingly, the standard coal consumption rate improves by $20.2 \mathrm{~g} / \mathrm{kWh}$ and from $19.8 \mathrm{~g} / \mathrm{kWh}$ respectively as extracted reheat steam increases. Figure 9 illustrates the variation of solar tower power generation, parabolic trough power generation and solar power efficiency with PH1 fully replaced under three different loads. Under 100\% load, $P_{\text {solar }}$ substantially increases from $20.3 \mathrm{MW}_{\mathrm{e}}$ to $70.8 \mathrm{MW}_{\mathrm{e}}$, and $\eta_{\text {solar }}$ improves from $18.5 \%$ to $20.8 \%$ as extracted reheat steam increases due to the higher proportion of solar tower energy that contains more exergy. Under $75 \%$ and $50 \%$ load, $P_{s t}$ shows a linear increase and reaches 31.8 $\mathrm{MW}_{\mathrm{e}}$ and 20.4 $\mathrm{MW}_{\mathrm{e}}$, respectively. $\eta_{\text {solar }}$ slightly deteriorates under part loads when solar energy from the solar tower is not introduced, which is $18.1 \%$ and $17.1 \%$ in $75 \%$ and $50 \%$ load, and then enhances to $20.6 \%$ and $20.2 \%$ as extracted reheat steam increases. 


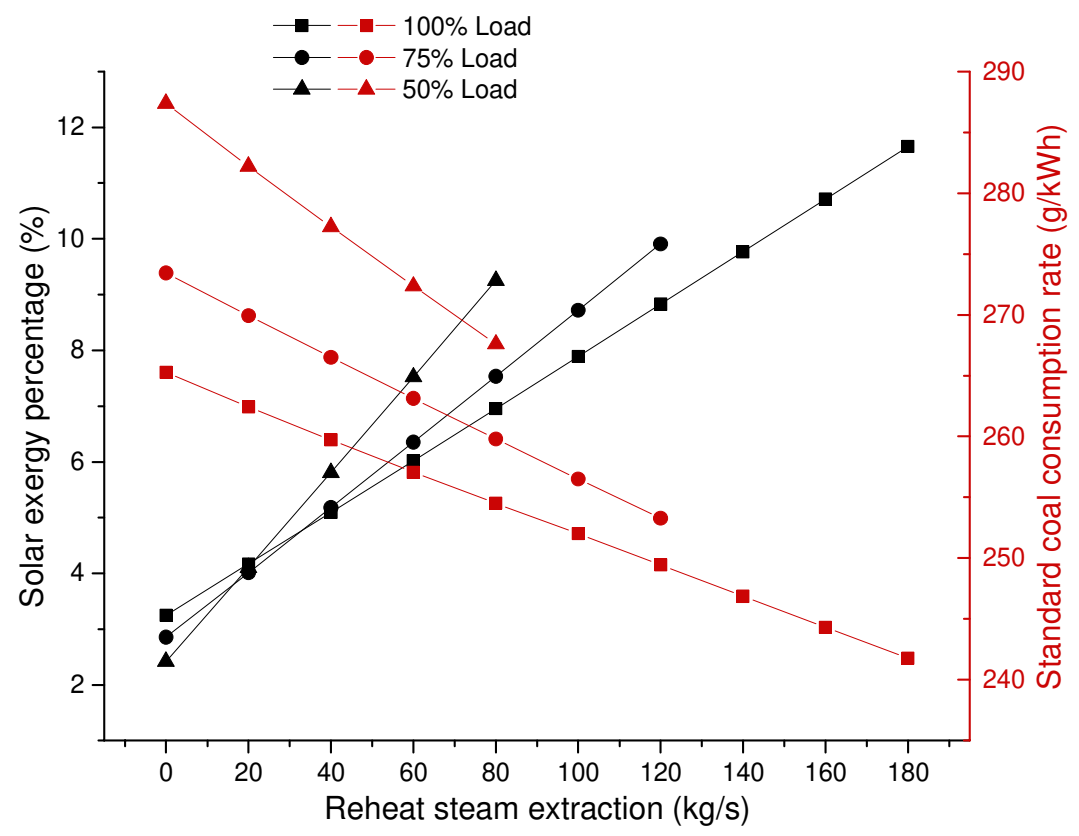

Figure 8 . The variation of solar exergy percentage and standard coal consumption rate under three loads

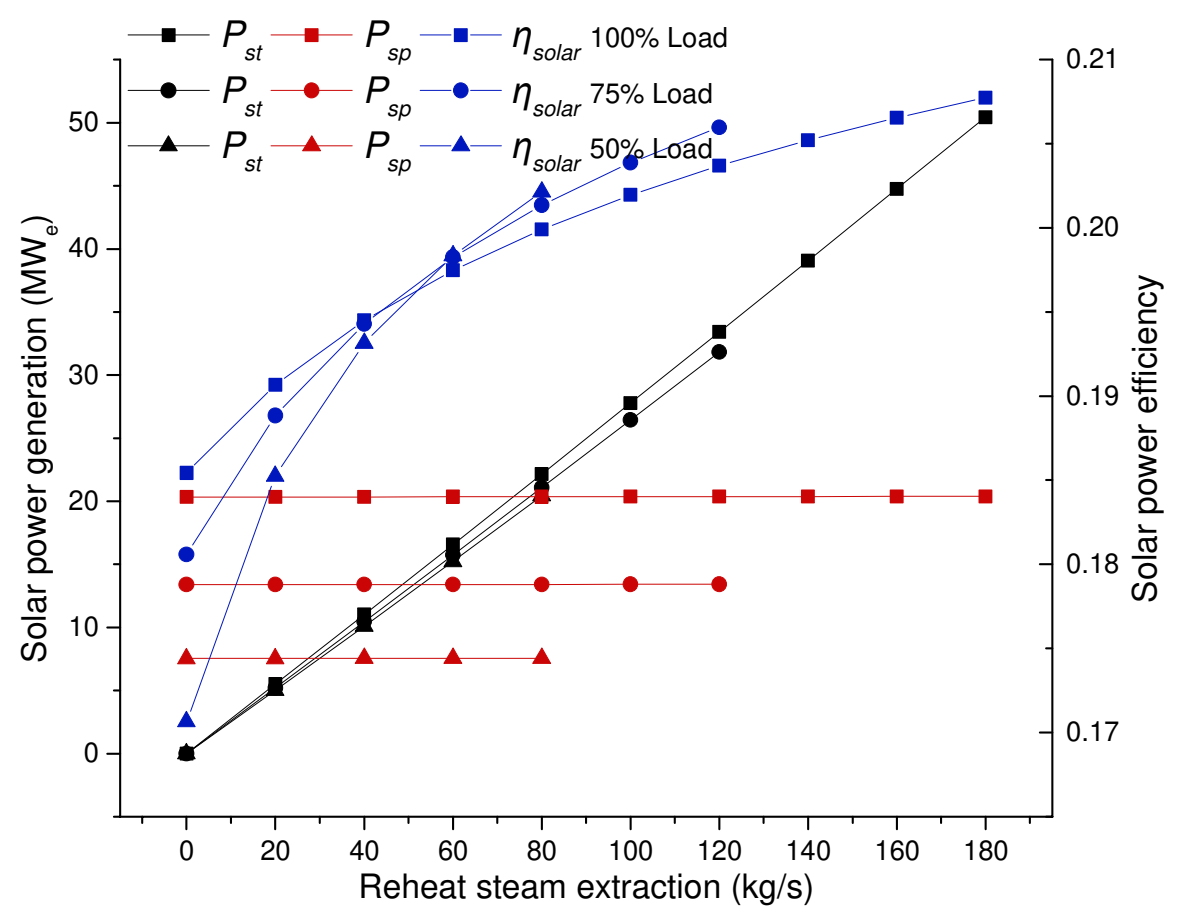

Figure 9. The variation of solar power generation and solar power efficiency under three loads

The variation of system efficiency and boiler efficiency under 100\%, 75\% and 50\% load, with PH1 fully replaced, are displayed in Figure 10. Under three different loads, 
$\eta_{\text {STPG }}$ shows a dropping trend as extracted reheat steam increases, which decreases from $42.8 \%$ to $39.8 \%$, from $41.9 \%$ to $39.5 \%$ and from $40.3 \%$ to $38.1 \%$ under three different loads, respectively, because of the increasing solar energy percentage. Under $100 \%$ load, $\eta_{\text {boiler }}$ is slightly enhanced at first due to the opposite effects of two energy flows on the reheat steam flow rate but then decreases as extracted reheat steam increases. Under $75 \%$ and $50 \%$ loads, $\eta_{\text {boiler }}$ slightly declines from $93.2 \%$ to $92.9 \%$ and from $92.8 \%$ to $92.5 \%$ as extracted reheat steam increases due to the deviation from the designed point, respectively.

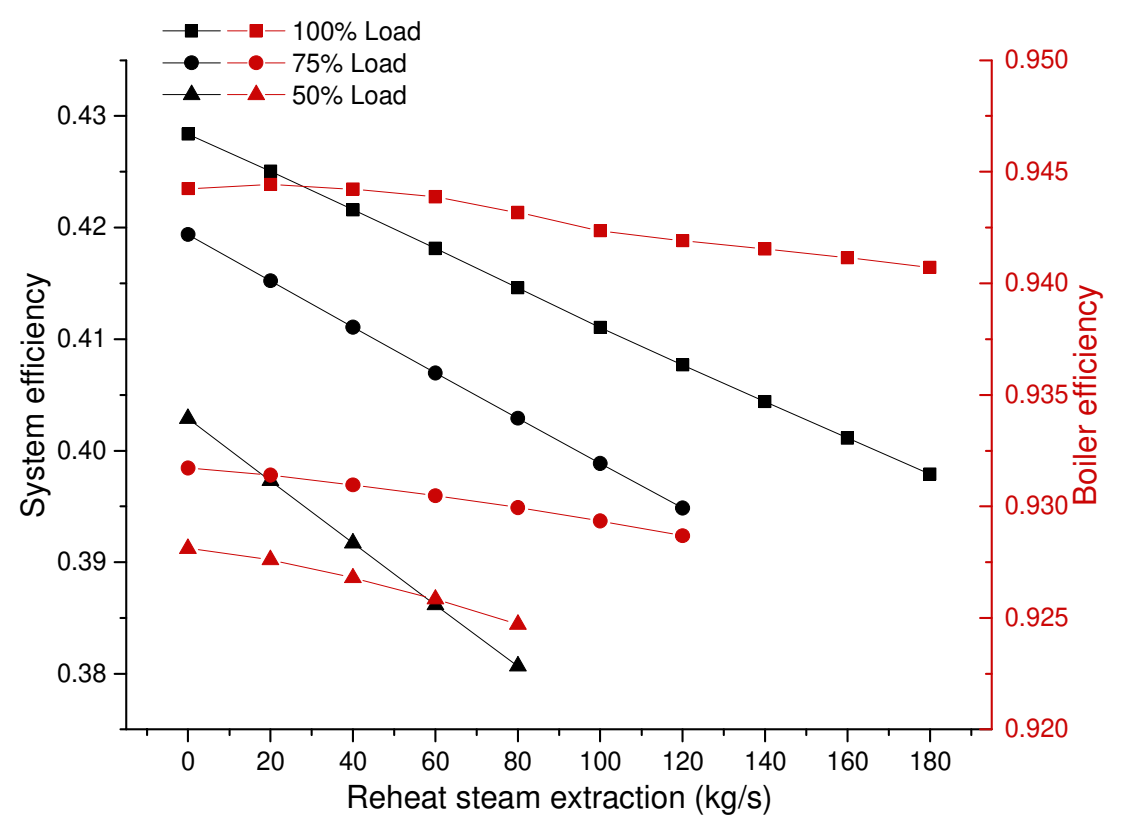

Figure 10. The effects of introduced solar energy on system efficiency and boiler efficiency under three loads

\subsubsection{Daily operational performance}

In this STPG system, there are three sources of energy: the chemical energy of coal fuel and solar thermal energy collected by heliostats and by the parabolic troughs. The STPG system has different coupled operational modes according to different solar 
load and thermal energy in storage, as shown in Figure 11. When the thermal energy from parabolic troughs $\left(Q_{c o l, e f f}\right)$ and medium-temperature molten salt storage $\left(Q_{m s}\right)$ is sufficient to provide the maximum solar energy that the feed-water can absorb $\left(Q_{f w, \max }\right)$, the energy introduced into the feed-water is $Q_{f w, \max }$. Otherwise, the introduced energy is 0 . The feed-water extraction leads to the variation of boiler operation, as well as the maximum solar energy that the reheat steam can absorb $\left(Q_{r s, \max }\right)$. When the thermal energy from receiver $\left(Q_{r e c}\right)$ and high-temperature molten salt storage $\left(Q_{h s}\right)$ is sufficient to provide the maximum solar energy reheat steam can absorb $\left(Q_{r s, \max }\right)$, the energy introduced into the reheat steam is $Q_{r s, \max }$, according to the solar energy absorbed by feed-water. 


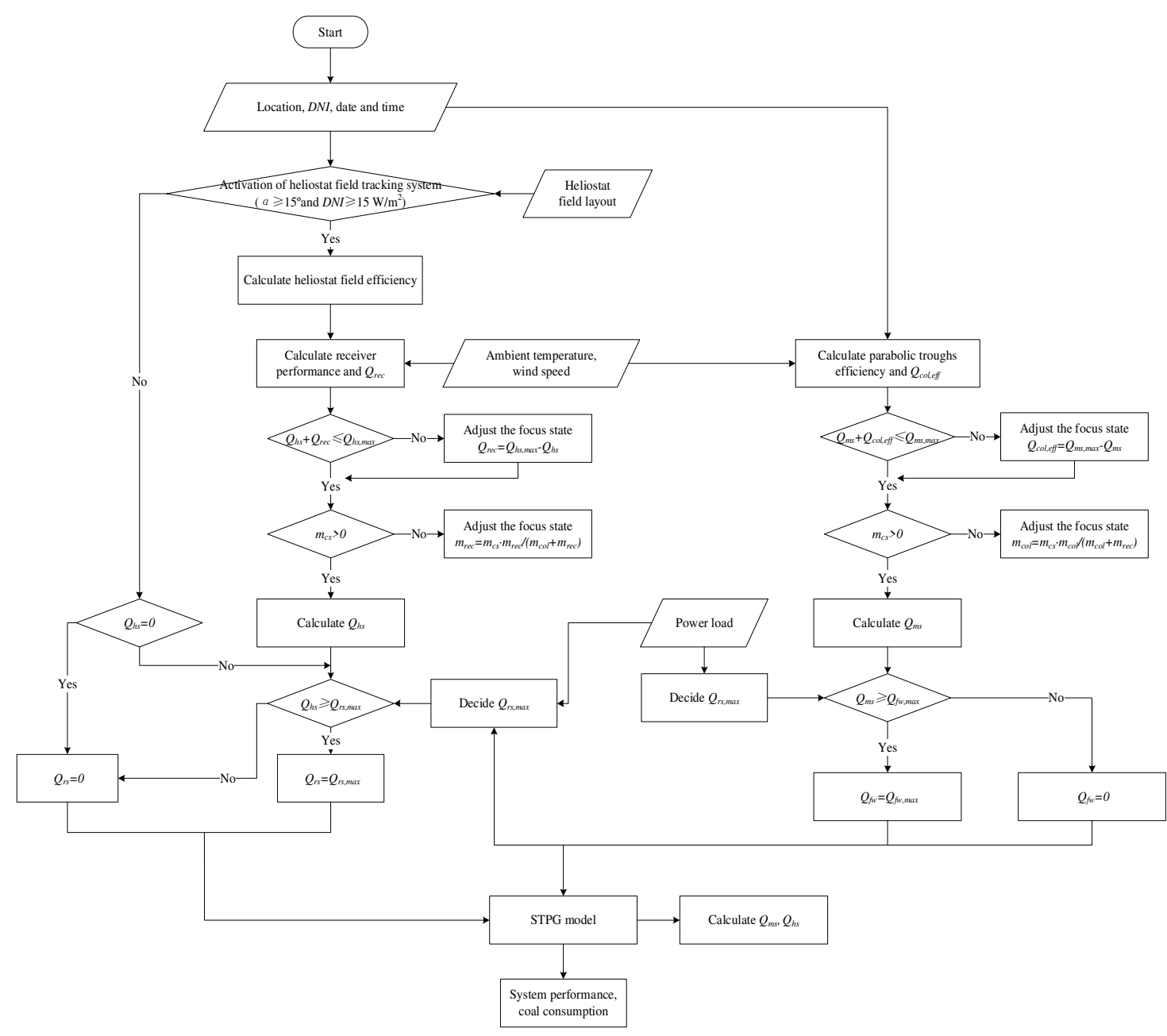

Figure 11. The flow chart of the operational strategy in the coupled mode.

The variation of system performance in four typical days is investigated under $100 \%, 75 \%$ and $50 \%$ loads in this section and presented in Table 6. The STPG achieves the lowest coal consumption at the summer solstice and has the highest coal consumption in the winter solstice. For $100 \%$ load, a maximum of $940.2 \mathrm{MWh}$ electricity is produced by solar energy, that results in 266.6-tonne coal consumption saved and 732.4-tonne $\mathrm{CO}_{2}$ emissions reduction in the summer solstice, while at the winter solstice the solar power generation is $492.4 \mathrm{MWh}$ and leads to 134.5 -tonne coal consumption saved. For $75 \%$ load, the maximum solar power generation is $700.2 \mathrm{MWh}$, while the minimum solar power generation is $494.9 \mathrm{MWh}$, which is basically the same 
with that under $100 \%$ load. The boost of solar output power does not cause the improvement of solar power generation from $75 \%$ load to $100 \%$ load in the winter solstice. That means the solar power generation is restricted to the TES capacity in the vernal equinox, summer solstice and autumnal equinox, while solar energy is fully utilised in the winter solstice. For 50\% load, the difference between performances in the summer and winter solstice is 28.1-tonne coal consumption and 77.2-tonne $\mathrm{CO}_{2}$ emissions.

Table 6. System daily performance in four typical days

\begin{tabular}{llllll}
\hline Typical day & $\begin{array}{l}\text { Coal } \\
\text { consumption } \\
\text { (tonne) }\end{array}$ & $\begin{array}{l}\text { Solar } \\
\text { power } \\
\text { generation } \\
(\mathrm{MWh})\end{array}$ & $\begin{array}{l}\text { Solar } \\
\text { power } \\
\text { efficiency } \\
(\%)\end{array}$ & $\begin{array}{l}\text { Coal } \\
\text { consumption } \\
\text { reduction } \\
\text { (tonne) }\end{array}$ & $\begin{array}{l}\mathrm{CO}_{2} \\
\text { emission } \\
\text { reduction } \\
\text { (tonne) }\end{array}$ \\
\hline 100\% Load & & & & & \\
Vernal equinox & 4005.0 & 737.5 & 16.7 & 210.0 & 576.8 \\
Summer solstice & 3987.4 & 940.2 & 21.3 & 266.6 & 732.4 \\
Autumnal equinox & 3984.6 & 868.0 & 19.6 & 247.0 & 678.5 \\
Winter solstice & 4026.0 & 492.4 & 11.1 & 134.5 & 369.4 \\
$75 \%$ Load & & & & & \\
Vernal equinox & 3089.0 & 564.5 & 12.8 & 163.1 & 447.9 \\
Summer solstice & 3066.2 & 700.2 & 15.8 & 202.8 & 557.0 \\
Autumnal equinox & 3073.8 & 655.0 & 14.8 & 189.5 & 520.6 \\
Winter solstice & 3079.1 & 494.9 & 11.2 & 143.5 & 394.2 \\
50\% Load & & & & & 315.1 \\
Vernal equinox & 2137.0 & 417.0 & 9.4 & 114.7 & 361.0 \\
Summer solstice & 2127.1 & 472.9 & 10.7 & 131.4 & 338.0 \\
Autumnal equinox & 2132.1 & 444.9 & 10.1 & 123.1 & 283.8 \\
Winter solstice & 2142.1 & 378.9 & 8.6 & 103.3 & \\
\hline
\end{tabular}

The hourly operational performance, including the remained mass of hightemperature molten salt $\left(m_{h s}\right)$ in hot tank 1 and medium-temperature molten salt $\left(m_{m s}\right)$ in hot tank 2, solar tower and parabolic troughs power output $\left(P_{s t}\right.$ and $\left.P_{s p}\right)$ and standard coal consumption rate $\left(b_{s t}\right)$ in four typical days under $75 \%$ load are illustrated 
in Figure 12 as an example. In summer solstice, STPG operates in the coupled mode for $15 \mathrm{~h}$ and remains more than three hours required thermal energy in TES at the end of the day. Solar energy produces electricity from $8 \mathrm{~h}$ and molten salt is run out at $11 \mathrm{~h}$. In winter solstice, STPG operates with solar tower and parabolic troughs coupled for $13 \mathrm{~h}$, of which with solar tower coupled alone for $8 \mathrm{~h}$, due to the serious deterioration of parabolic troughs efficiency. In vernal equinox and the autumnal equinox, STPG has similar performances. However, solar energy components start to work at $10 \mathrm{~h}$ in vernal equinox and $9 \mathrm{~h}$ in autumnal equinox, due to the different DNI values. Besides, this three-tank TES operates more flexible than the conventional two-tank TES, in which the molten salt is dispatched according to the requirement of two solar fields to avoid the waste of TES capacity.

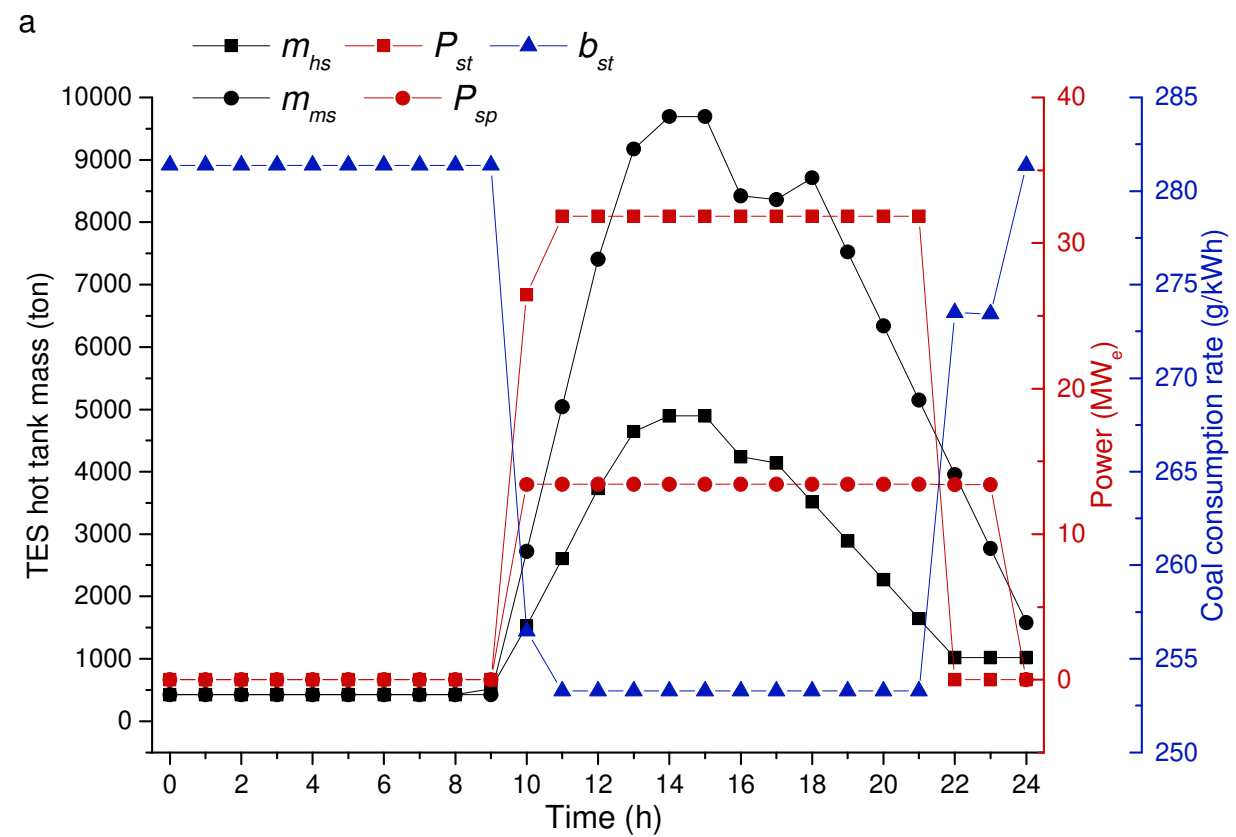



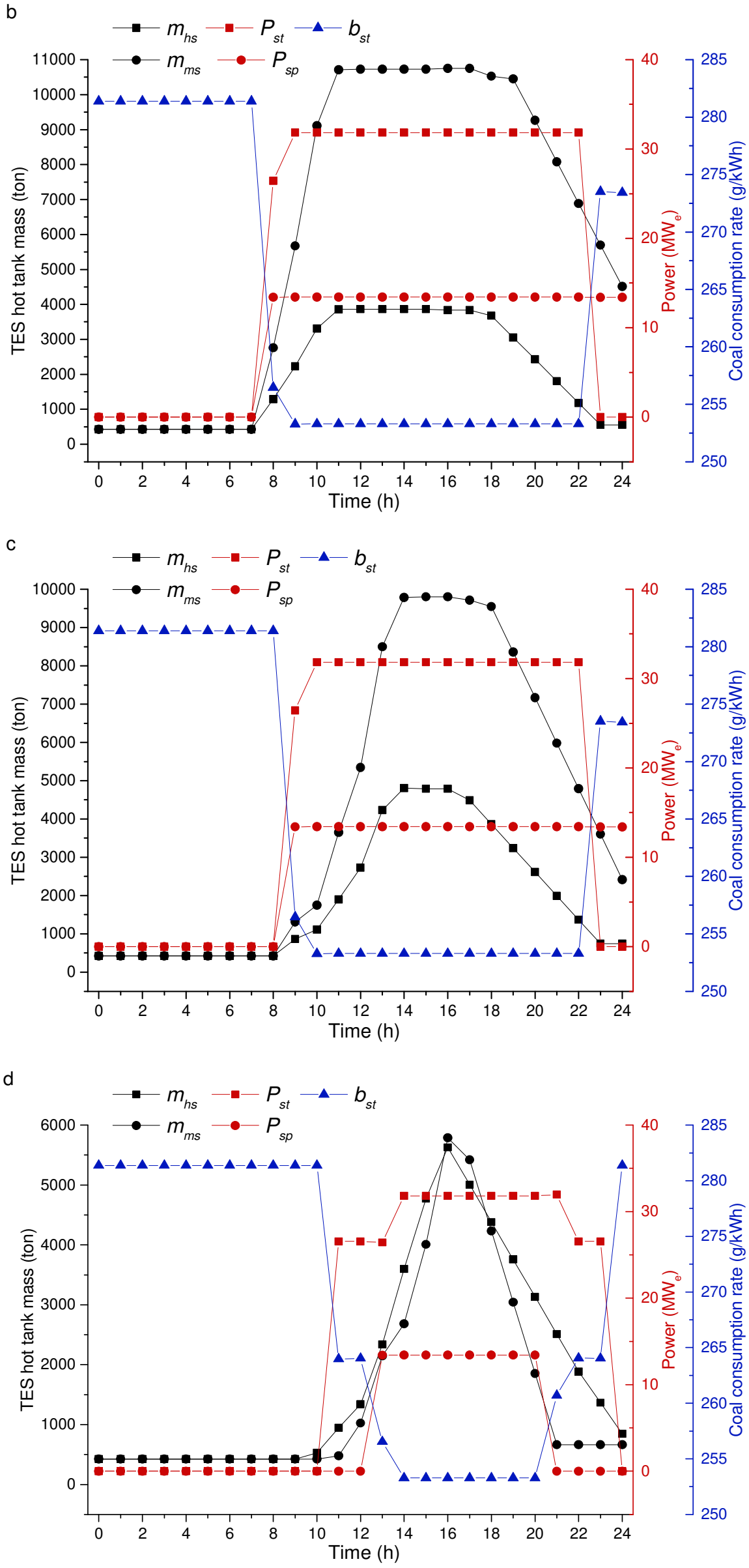
Figure 12. Hourly operational performance under $75 \%$ load in (a) vernal equinox, (b)

summer solstice, (c) autumnal equinox, (d) winter solstice

\subsubsection{Technical-economic performance}

Table 7 shows the comparison of SPCG, STCG and STPG in the technicaleconomic performance aspect. The cost for the solar field is obtained from System Advisor Model, including the cost of heliostats, tower, receiver and the cost of parabolic troughs, site improvement and the land for parabolic troughs and heliostats [46]. As shown in Table 7, the parabolic troughs cost $M \$ 64.1$ with solar power output maximised at $20.3 \mathrm{MW}_{\mathrm{e}}$ in SPCG. The heliostat field costs $\mathrm{M} \$ 163.9$ with solar power output maximised at $39.3 \mathrm{MW}_{\mathrm{e}}$ in STCG. In STPG, the solar power output is maximised at $70.8 \mathrm{MW}_{\mathrm{e}}$, which is improved by $11.2 \mathrm{MW}_{\mathrm{e}}(18.8 \%)$ compared with the sum of power output from the solar tower and parabolic troughs $\left(59.6 \mathrm{MW}_{\mathrm{e}}\right)$.

Table 7. Technical-economic performance comparison of SPCG, STCG and STPG

\begin{tabular}{|c|c|c|c|c|c|}
\hline & & SPCG & STCG & STPG & Unit \\
\hline \multirow{9}{*}{$\begin{array}{l}\text { Technical } \\
\text { performance }\end{array}$} & $100 \%$ load & & & & \\
\hline & Limit of solar power output & 20.3 & 39.3 & 70.8 & $\mathrm{MW}_{\mathrm{e}}$ \\
\hline & Solar power efficiency & 18.5 & 21.8 & 20.8 & $\%$ \\
\hline & $75 \%$ load & & & & \\
\hline & Limit of solar power output & 13.4 & 26.6 & 45.3 & $\mathrm{MW}_{\mathrm{e}}$ \\
\hline & Solar power efficiency & 18.1 & 21.9 & 20.6 & $\%$ \\
\hline & $50 \%$ load & & & & \\
\hline & Limit of solar power output & 7.5 & 17.9 & 28.0 & $\mathrm{MW}_{\mathrm{e}}$ \\
\hline & Solar power efficiency & 17.1 & 21.7 & 20.2 & $\%$ \\
\hline \multirow{8}{*}{$\begin{array}{l}\text { Economic } \\
\text { performance }\end{array}$} & Heliostats & - & 88.0 & 88.0 & M\$ \\
\hline & Site improvement for heliostats & - & 9.7 & 9.7 & $\mathrm{M} \$$ \\
\hline & Tower & - & 14.7 & 14.7 & $\mathrm{M} \$$ \\
\hline & Receiver & - & 43.1 & 43.1 & $\mathrm{M} \$$ \\
\hline & Land cost of heliostat field & - & 8.4 & 8.4 & $\mathrm{M} \$$ \\
\hline & Parabolic troughs & 51.9 & - & 51.9 & M\$ \\
\hline & Site improvement for parabolic troughs & 8.6 & - & 8.6 & M\$ \\
\hline & Land cost of parabolic troughs & 3.6 & - & 3.6 & $\mathrm{M} \$$ \\
\hline
\end{tabular}




\subsubsection{Challenges and opportunities}

The system is also confronted with challenges of operation due to its complex configuration. The control process of the boiler, which is integrated with solar tower energy, needs to be determined according to both the required power load and the solar energy absorbed by feed-water.

The annual performance isn't investigated due to the complexity of the system operation, considering different limit for boiler integration under different power load and the effects of feed-water extraction. However, the scheme performance is analysed for four typical days in a year. Besides, there is possibility of solar energy integrating bottom cycle as a base load while the gas turbines to meet the peak load topping cycle, and this topic isn't within scope of this paper.

\section{Conclusions}

This work investigated the maximum absorbed solar energy in a $600 \mathrm{MW}_{\mathrm{e}} \mathrm{STPG}$, in which feed-water PH1 is extracted and heated by parabolic troughs while part of reheat steam is heated by the solar tower. The interaction of different solar input is revealed for the first time. Then performance of STPG under 100\% load, 75\% load 50\% load are explored and hourly operational performance in four typical days are analysed. The conclusions derived from this study are as follows:

(1) The increase of feed-water extraction results in the growth of maximum introduced solar energy in reheat steam because the two extraction flows have reverse effects on the reheat steam flow rate, which are partly counteracted. With PH1 feedwater extracted percentage increasing from 0 to $100 \%$, the maximum reheat steam 
extraction percentage increases from $38.8 \%$ to $42.3 \%$, from $33.6 \%$ to $38.3 \%$ and from $34.7 \%$ to $38.0 \%$, and maximum solar energy absorbed by reheat steam is enhanced from 89.0 $\mathrm{MW}_{\text {th }}$ to $109.2 \mathrm{MW}_{\text {th }}$, from $57.3 \mathrm{MW}_{\text {th }}$ to $68.7 \mathrm{MW}_{\text {th }}$ and from $39.0 \mathrm{MW}_{\text {th }}$ to 44.5 $\mathrm{MW}_{\text {th }}$ under $100 \%, 75 \%$ and $50 \%$ loads, respectively.

(2) For the $100 \%$ feed-water extraction in comparison to $0 \%$, the minimum standard coal consumption rates are improved from $255.0 \mathrm{~g} / \mathrm{kWh}$ to $241.8 \mathrm{~g} / \mathrm{kWh}$, from $264.0 \mathrm{~g} / \mathrm{kWh}$ to $253.3 \mathrm{~g} / \mathrm{kWh}$ and from $276.7 \mathrm{~g} / \mathrm{kWh}$ to $267.6 \mathrm{~g} / \mathrm{kWh}$ under three loads, while the minimum $\mathrm{CO}_{2}$ emission decreases from $701.4 \mathrm{~g} / \mathrm{kWh}$ to $665.1 \mathrm{~g} / \mathrm{kWh}$, from $721.1 \mathrm{~g} / \mathrm{kWh}$ to $692.0 \mathrm{~g} / \mathrm{kWh}$ and from $752.0 \mathrm{~g} / \mathrm{kWh}$ to $727.5 \mathrm{~g} / \mathrm{kWh}$, respectively.

(3) With PH1 completely replaced, solar tower power generation shows a linear increase and reaches 50.4 $\mathrm{MW}_{\mathrm{e}}, 31.8 \mathrm{MW}_{\mathrm{e}}$ and 20.4 $\mathrm{MW}_{\mathrm{e}}$, while the solar power efficiency is improved from $18.5 \%$ to $20.8 \%$, from $18.1 \%$ to $20.6 \%$ and from $17.1 \%$ to 20.2 as extracted reheat steam increases under three load scenarios.

(4) Under $100 \%, 75 \%$ and $50 \%$ loads, the system efficiency decreases from $42.8 \%$ to $39.8 \%$, from $41.9 \%$ to $39.5 \%$ and from $40.3 \%$ to $38.1 \%$ as extracted reheat steam increases and $100 \%$ feed-water extracted from PH1, because of the expansion of solar energy proportion and efficiency drop of the boiler. Under $100 \%$ load, the boiler efficiency shows a slight recovery and then decreases as extracted reheat steam increases, which continuously declines by approximately $0.3 \%$ under $75 \%$ and $50 \%$ loads due to the deviation from the designed point, respectively.

(5) The lowest coal consumption is achieved in summer solstice and the highest coal consumption is obtained in the winter solstice. The maximum daily coal 
consumption reductions are 266.6-tonne, 202.8-tonne and 131.4-tonne under the three different loads.

\section{Acknowledgements}

The research work is supported by the China National Natural Science Foundation (No. 51776063), Science Fund for Creative Research Groups of the National Natural Science Foundation of China (No. 51821004), National Basic Research Program of China (2015CB251505), the Fundamental Research Funds for the Central Universities (2019QN010) and China Scholarship Council with support from Cranfield University as host institute.

\section{Nomenclature}

\begin{tabular}{|c|l|l|}
\hline Symbol & Description & Unit \\
\hline$A_{f}$ & effective area of heliostats & $\mathrm{m}^{2}$ \\
\hline$A_{\text {rec }}$ & the surface area of the tube bundle in the receiver & $\mathrm{m}^{2}$ \\
\hline$A_{\text {net }}$ & net aperture area of parabolic troughs & $\mathrm{m}^{2}$ \\
\hline$b_{\text {st }}$ & standard coal consumption rate & $\mathrm{g} / \mathrm{kWh}$ \\
\hline $\cos \theta_{i}$ & cosine factor of heliostats & - \\
\hline$D N I$ & direct normal irradiance & $\mathrm{W} / \mathrm{m}^{2}$ \\
\hline$e_{\text {shad }}$ & shading losses factor of parabolic troughs & - \\
\hline$e_{\text {end }}$ & end-loss factor of parabolic troughs & - \\
\hline$e_{\text {clean }}$ & actual mirror cleanliness factor of parabolic troughs & - \\
\hline$e_{\text {avail }}$ & field availability of parabolic troughs & - \\
\hline$E x_{\text {boiler }}$ & exergy absorbed in boiler & $\mathrm{MW}$ \\
\hline$E x_{r s}$ & exergy absorbed by extracted reheat steam & $\mathrm{MW}$ th \\
\hline
\end{tabular}




\begin{tabular}{|c|c|c|}
\hline$E x_{f w}$ & exergy absorbed by extracted feed-water & $\mathrm{MW}_{\text {th }}$ \\
\hline$f_{s b_{i}}$ & shading and blocking factor & - \\
\hline$f_{a t_{i}}$ & atmospheric attenuation factor & - \\
\hline \multirow[t]{2}{*}{$f_{\text {int }_{i}}$} & interception factor & - \\
\hline & cosine losses factor of parabolic troughs & - \\
\hline$m_{i}$ & thermal storage fluid masses in the hot tank at time point $i$ & $\mathrm{~kg} / \mathrm{s}$ \\
\hline$m_{\text {load }}$ & inlet mass flows of the hot tank & $\mathrm{kg} / \mathrm{s}$ \\
\hline$m_{\text {unload }}$ & outlet mass flows of the hot tank & $\mathrm{kg} / \mathrm{s}$ \\
\hline$m_{h s}$ & mass of high-temperature molten salt in the hot tank 1 & tonne \\
\hline$m_{m s}$ & mass of medium-temperature molten salt in the hot tank 2 & tonne \\
\hline$n$ & number of heliostats & - \\
\hline$P_{S T P G}$ & power output from the integrated system & $\mathrm{MW}_{\mathrm{e}}$ \\
\hline$P_{s t}$ & power output from the solar tower energy & $\mathrm{MW}_{\mathrm{e}}$ \\
\hline$P_{s p}$ & power output from the parabolic trough energy & $\mathrm{MW}_{\mathrm{e}}$ \\
\hline$Q_{\text {col.eff }}$ & thermal energy absorbed by the working fluid in parabolic troughs & $\mathrm{MW}_{\text {th }}$ \\
\hline$Q_{o s}$ & thermal energy provided by thermal oil storage & $\mathrm{MW}_{\text {th }}$ \\
\hline$Q_{f w, \max }$ & maximum energy absorbed by feed-water extraction & $\mathrm{MW}_{\text {th }}$ \\
\hline$Q_{r s, \max }$ & maximum energy absorbed by reheat steam extraction & $\mathrm{MW}_{\text {th }}$ \\
\hline$Q_{\text {rec }}$ & thermal energy absorbed by the working fluid in the receiver & $\mathrm{MW}_{\text {th }}$ \\
\hline$Q_{m s}$ & thermal energy provided by molten salt storage & $\mathrm{MW}_{\text {th }}$ \\
\hline$Q_{\text {receiver }}$ & solar energy reflected from the heliostat field to the receiver & $\mathrm{MW}_{\text {th }}$ \\
\hline$Q_{\text {loss }, o p t}$ & optical heat loss in the receiver & $\mathrm{MW}_{\text {th }}$ \\
\hline$Q_{\text {loss }, c o v}$ & convective heat loss of the receiver & $\mathrm{MW}_{\text {th }}$ \\
\hline$Q_{\text {loss, rad }}$ & radiation heat loss of receiver & $\mathrm{MW}_{\text {th }}$ \\
\hline$Q_{\text {col }}$ & solar energy collected by parabolic troughs & $\mathrm{MW}_{\text {th }}$ \\
\hline$Q_{\text {col,loss }}$ & heat losses that occur in the collectors & $\mathrm{MW}_{\text {th }}$ \\
\hline$Q_{\text {pipe,loss }}$ & heat losses that occur in the pipes of parabolic troughs & $\mathrm{MW}_{\text {th }}$ \\
\hline$Q_{\text {loss }, T E S}$ & heat loss in the hot tank & $\mathrm{MW}_{\text {th }}$ \\
\hline$Q_{s t}$ & effective incident solar energy for heliostats & $\mathrm{MW}_{\text {th }}$ \\
\hline
\end{tabular}




\begin{tabular}{|c|l|l|}
\hline$Q_{s p}$ & effective incident solar energy for parabolic troughs & $\mathrm{MW}_{\text {th }}$ \\
\hline$Q_{c o a l}$ & thermal energy provided by coal fuel & $\mathrm{MW}_{\text {th }}$ \\
\hline$T_{\text {rec }}$ & the surface temperature of the tube bundle in the receiver & $\mathrm{K}$ \\
\hline$T_{a m b}$ & ambient air temperature & $\mathrm{K}$ \\
\hline$T_{\text {in }}$ & fluid temperature entering the receiver & $\mathrm{K}$ \\
\hline$T_{\text {out }}$ & fluid temperature entering the receiver & $\mathrm{K}$ \\
\hline$t_{\text {int }}$ & time interval & $\mathrm{s}$ \\
\hline$\alpha$ & $\begin{array}{l}\text { convective heat transfer coefficient between the receiver surface and the } \\
\text { surrounding air }\end{array}$ & $\mathrm{W} /\left(\mathrm{m}^{2}\right.$ \\
\hline$\varepsilon$ & the emissivity of the receiver surface & $\mathrm{K})$ \\
\hline$\eta_{\text {hel }}$ & efficiency of an individual heliostat & - \\
\hline$\eta_{\text {opt }}$ & the optical efficiency of the receiver surface & - \\
\hline$\eta_{\text {colopt }}$ & peak optical efficiency of parabolic troughs & - \\
\hline$\eta_{s t}$ & solar tower power generation efficiency & - \\
\hline$\eta_{s p}$ & solar parabolic trough power generation efficiency & - \\
\hline$\eta_{\text {solar }}$ & total solar power generation efficiency & - \\
\hline$\eta_{\text {boiler }}$ & boiler efficiency & - \\
\hline$\eta_{S T P G}$ & system power generation efficiency & - \\
\hline$\lambda_{\text {ex,st }}$ & solar exergy percentages of solar tower & - \\
\hline$\lambda_{\text {ex,sp }}$ & solar exergy percentages of parabolic troughs & - \\
\hline$\rho_{i}$ & effective reflectivity of heliostat with soiling & - \\
\hline & & - \\
\hline
\end{tabular}

\section{References}

[1] Oberschelp C, Pfister S, Raptis C E, et al. Global emission hotspots of coal power generation. Nature Sustainability, 2019, 2(2): 113-121. https://doi.org/10.1038/s41893-019-0221-6

[2] Petroleum B. BP Statistical Review of World Energy Report. BP: London, UK, 
2019.

[3] Chu F, Gao Q, Li S, et al. Mass transfer characteristic of ammonia escape and energy penalty analysis in the regeneration process. Applied Energy, 2020, 258: 113975. https://doi.org/10.1016/j.apenergy.2019.113975

[4] Yang H, Pollitt M. Incorporating both undesirable outputs and uncontrollable variables into DEA: The performance of Chinese coal-fired power plants. European journal of operational research, 2009, 197(3): 1095-1105. https://doi.org/10.1016/j.ejor.2007.12.052

[5] Forrester J. The Value of CSP with Thermal Energy Storage in Providing Grid Stability. Energy

Procedia.

2014

49:1632-41. https://doi.org/10.1016/j.egypro.2014.03.172

[6] Yang Y, Yan Q, Zhai R, et al. An efficient way to use medium-or-low temperature solar heat for power generation-integration into conventional power plant. Applied thermal engineering, 2011, 31(2-3): 157-162. https://doi.org/10.1016/j.applthermaleng.2010.08.024

[7] Zoschak R J, Wu S F. Studies of the direct input of solar energy to a fossil-fueled central station steam power plant. Solar Energy, 1975, 17(5): 297-305. https://doi.org/10.1016/0038-092X(75)90047-X

[8] Hu E, Yang Y, Nishimura A, Yilmaz F, Kouzani A. Solar thermal aided power $\begin{array}{llll}\text { generation. } & \text { Applied } & \text { Energy. } & \text { 2010; }\end{array}$ https://doi.org/10.1016/j.apenergy.2009.10.025

[9] Yan Q, Yang Y, Nishimura A, et al. Multi-point and multi-level solar integration 
into a conventional coal-fired power plant. Energy \& fuels, 2010, 24(7): 37333738. https://doi.org/10.1021/ef9012906

[10] Popov D. An option for solar thermal repowering of fossil fuel fired power plants. Solar Energy, 2011, 85(2): 344-349. https://doi.org/10.1016/j.solener.2010.11.017

[11] Rech S, Lazzaretto A, Grigolon E. Optimum integration of concentrating solar technologies in a real coal-fired power plant for fuel saving. Energy conversion and management, 2018 178: 299-310. https://doi.org/10.1016/j.enconman.2018.10.026

[12] Wang J, Duan L, Yang Y, Yang Z, Yang L. Study on the general system integration optimization method of the solar aided coal-fired power generation system. Energy. 2019;169:660-73. https://doi.org/10.1016/j.energy.2018.12.054

[13] Pierce W, Gauché P, von Backström T, et al. A comparison of solar aided power generation (SAPG) and stand-alone concentrating solar power (CSP): A South African case study. Applied Thermal Engineering, 2013, 61(2): 657-662. https://doi.org/10.1016/j.applthermaleng.2013.08.014

[14] Hong H, Peng S, Zhang H, et al. Performance assessment of hybrid solar energy and coal-fired power plant based on feed-water preheating. Energy, 2017, 128: 830-838. https://doi.org/10.1016/j.energy.2017.04.050

[15] Li J, Yu X, Wang J, et al. Coupling performance analysis of a solar aided coal-fired power plant. Applied Thermal Engineering, 2016, 106: 613-624. https://doi.org/10.1016/j.applthermaleng.2016.06.033

[16] Junjie W, Hongjuan H, Yongping Y. Research on the Performance of Coal-fired 
Power System Integrated with Solar Energy. Energy Procedia. 2014;61:791-4. https://doi.org/10.1016/j.egypro.2014.11.966

[17] Peng S, Hong H, Wang Y, Wang Z, Jin H. Off-design thermodynamic performances on typical days of a 330MW solar aided coal-fired power plant in $\begin{array}{llll}\text { China. } & \text { Applied } & \text { 2014; } & \text { Energy. }\end{array}$ https://doi.org/10.1016/j.apenergy.2014.01.096

[18] Shagdar E, Lougou B G, Shuai Y, et al. Performance analysis and techno-economic evaluation of $300 \mathrm{MW}$ solar-assisted power generation system in the whole operation conditions. Applied Energy, 2020, 264: 114744. https://doi.org/10.1016/j.apenergy.2020.114744

[19] Wu J, Hou H, Yang Y, Hu E. Annual performance of a solar aided coal-fired power generation system (SACPG) with various solar field areas and thermal energy storage capacity. Applied Energy. 2015;157:123-33. https://doi.org/10.1016/j.apenergy.2015.08.022

[20] Wu J, Hou H, Yang Y. Annual economic performance of a solar-aided $600 \mathrm{MW}$ coal-fired power generation system under different tracking modes, aperture areas, and storage capacities. Applied Thermal Engineering. 2016;104:319-32. https://doi.org/10.1016/j.applthermaleng.2016.05.057

[21] Suresh MVJJ, Reddy KS, Kolar AK. 4-E (Energy, Exergy, Environment, and Economic) analysis of solar thermal aided coal-fired power plants. Energy for Sustainable Development. 2010;14:267-79. https://doi.org/10.1016/j.esd.2010.09.002 
[22] Adibhatla S, Kaushik S C. Energy, exergy, economic and environmental (4E) analyses of a conceptual solar aided coal fired 500 MWe thermal power plant with thermal energy storage option. Sustainable Energy Technologies and Assessments, 2017, 21: 89-99. https://doi.org/10.1016/j.seta.2017.05.002

[23] Wang R, Sun J, Hong H, et al. Comprehensive evaluation for different modes of solar-aided coal-fired power generation system under common framework regarding both coal-savability and efficiency-promotability. Energy, 2018, 143: 151-167. https://doi.org/10.1016/j.energy.2017.10.085

[24] Reddy V S, Kaushik S C, Tyagi S K. Exergetic analysis of solar concentrator aided coal fired super critical thermal power plant (SACSCTPT). Clean Technologies and Environmental Policy, 2013, 15(1): 133-145. https://doi.org/10.1007/s10098012-0492-3

[25] Feng L, Liao H, Wang P, Huang J, Schumacher KL. A technique to avoid twophase flow in solar collector tubes of the direct steam generation system for a solar aided power generation plant. Applied Thermal Engineering. 2019;148:568-77. https://doi.org/10.1016/j.applthermaleng.2018.10.029

[26] Huang C, Hou H, Hu E, Yu G, Peng H, Yang Y, et al. Performance maximization of a solar aided power generation (SAPG) plant with a direct air-cooled condenser in power-boosting mode. Energy. 2019;175:891-9. https://doi.org/10.1016/j.energy.2019.03.133

[27] Huang C, Hou H, Hu E, Yu G, Peng H, Zhao J, et al. Stabilizing operation of a solar aided power generation (SAPG) plant by adjusting the burners' tilt and 
attemperation flows in the boiler. Energy. 2019;173:1208-20. https://doi.org/10.1016/j.energy.2019.02.139

[28]Zhang N, Yu G, Huang C, Duan L, Hou H, H, E, Wang J. Full-day dynamic characteristics analysis of a solar aided coal-fired power plant in fuel saving mode. Energy 2020: 118424. https://doi.org/10.1016/j.energy.2020.118424

[29] Yan H, Li X, Liu M, Chong D, Yan J. Performance analysis of a solar-aided coalfired power plant in off-design working conditions and dynamic process. Energy $\begin{array}{llll}\text { Convers } & \text { Manage } & 2020, & 220:\end{array}$ https://doi.org/10.1016/j.enconman.2020.113059

[30] Zhu Y, Zhai R, Peng H, Yang Y. Exergy destruction analysis of solar tower aided coal-fired power generation system using exergy and advanced exergetic methods. Applied Thermal Engineering. 2016;108:339-46. https://doi.org/10.1016/j.applthermaleng.2016.07.116

[31] Li C, Zhai R, Yang Y, Patchigolla K, Oakey JE. Thermal performance of different integration schemes for a solar tower aided coal-fired power system. Energy Conversion and Management. 2018;171:1237-45. https://doi.org/10.1016/j.enconman.2018.06.064

[32] Zhang M, Du X, Pang L, Xu C, Yang L. Performance of double source boiler with coal-fired and solar power tower heat for supercritical power generating unit. Energy. 2016;104:64-75. https://doi.org/10.1016/j.energy.2016.03.111

[33] Zhang M, Xu C, Du X, Amjad M, Wen D. Off-design performance of concentrated solar heat and coal double-source boiler power generation with thermocline energy 
storage. $\quad$ Applied $\quad$ Energy. 2017;189:697-710. https://doi.org/10.1016/j.apenergy.2016.12.095

[34] Li C, Yang Z, Zhai R, Yang Y, Patchigolla K, Oakey JE. Off-design thermodynamic performances of a solar tower aided coal-fired power plant for different solar multiples with thermal energy storage. Energy. 2018;163:956-68. https://doi.org/10.1016/j.energy.2018.08.186

[35] Li C, Zhai R, Yang Y, Patchigolla K, Oakey JE, Turner P. Annual performance analysis and optimization of a solar tower aided coal-fired power plant. Applied Energy. 2019;237:440-56. https://doi.org/10.1016/j.apenergy.2019.01.003

[36]Li C, Zhai R, Zhang B, Chen W. Thermodynamic performance of a novel solar tower aided coal-fired power system. Applied Thermal Engineering. 2020: 115127. https://doi.org/10.1016/j.applthermaleng.2020.115127

[37] Liu H, Zhai R, Patchigolla K, et al. Performance analysis of a novel combined solar trough and tower aided coal-fired power generation system. Energy, 2020: 117597. https://doi.org/10.1016/j.energy.2020.117597

[38] Li C, Zhai R, Liu H, et al. Optimization of a heliostat field layout using hybrid PSO-GA algorithm. Applied Thermal Engineering, 2018, 128: 33-41. https://doi.org/10.1016/j.applthermaleng.2017.08.164

[39] Liu H, Zhai R, Fu J, et al. Optimization study of thermal-storage PV-CSP integrated system based on GA-PSO algorithm. Solar energy, 2019, 184: 391-409. https://doi.org/10.1016/j.solener.2019.04.017

[40] Wagner M J. Simulation and predictive performance modeling of utility-scale 
central receiver system power plants. 2008 .

[41] Weather Data of System Advisor Model, https://sam.nrel.gov/weather-data.html ; [accessed 21.04.20].

[42] Collado F J, Guallar J. A review of optimized design layouts for solar power tower plants with campo code. Renewable and Sustainable Energy Reviews, 2013, 20: 142-154. https://doi.org/10.1016/j.rser.2012.11.076

[43] Collado F J, Guallar J. Campo: Generation of regular heliostat fields. Renewable energy, 2012, 46: 49-59. https://doi.org/10.1016/j.renene.2012.03.011

[44] Zhai R, Liu H, Chen Y, et al. The daily and annual technical-economic analysis of the thermal storage PV-CSP system in two dispatch strategies. Energy Conversion and Management, $\quad$ 2017, $\quad$ 56-67. https://doi.org/10.1016/j.enconman.2017.10.040

[45] Zhai R, Liu H, Li C, et al. Analysis of a solar-aided coal-fired power generation system based on thermo-economic structural theory. Energy, 2016, 102: 375-387. https://doi.org/10.1016/j.energy.2016.02.086

[46] System Advisor Model, https://sam.nrel.gov; [accessed 05.09.20]. 